\title{
The petrogenesis of tin- and sulfide-lode mineralization at True Hill, southwestern New Brunswick
}

\author{
David Lentz* and A.L. McAllister \\ Department of Geology, University of New Brunswick, P.O. Box 4400, Fredericton, New Brunswick \\ E3B 5A3, Canada
}

Date Received February 25, 1990

Date Accepted June 12, 1990

\begin{abstract}
The subvolcanic True Hill granite porphyry in southwestern New Brunswick is genetically related to the Beech Hill series of granites of Devono-Carboniferous age. Three True Hill (TH) greisenised granite porphyry cupolas host Bi-Sn-Mo-W mineralized zones that have similarities to the nearby W-Mo-Bi orebodies at Mount Pleasant (MP).

Tin-bearing lodes $(0.03$ to $0.66 \mathrm{wt} . \% \mathrm{Sn})$ are developed along faults and fractures that cut both mineralized (Bi-Sn-MoW) and unmineralized True Hill granite porphyry and enclosing metasedimentary rocks of the Waweig Formation. Within these lodes, particularly the central Main lode, two types of mineralization are present, an early chlorite-sulfide assemblage (Stage 1) and a later hematite-phengite-cassiterite assemblage (Stage 2) that replaces, in part, the earlier Stage 1 assemblage. The Stage 1 assemblage consists of Fe-rich septechlorite, pyrite, low-Fe sphalerite, magnetite, chalcopyrite, galena, $\mathrm{Pb}-\mathrm{Bi}$ sulfides, tennantite, arsenopyrite and native $\mathrm{Ag}$. Fe-Mg-Mn metasomatism responsible for chloritization was coincident with leaching of alkali and alkali-earth elements during feldspar hydrolysis. The Stage 1 assemblage (chl-sulfide) was formed at low temperature $\left(<200^{\circ} \mathrm{C}\right)$ and low oxygen fugacity. The Stage 2 assemblage includes hematite, phengite, cassiterite and monazite with minor late quartz and fluorite. This assemblage was deposited at slightly higher temperatures $\left(200^{\circ}-300^{\circ} \mathrm{C}\right)$, higher oxygen fugacity (above hematite-magnetite buffer) and at moderate $\mathrm{pH}$ 's (<musc-Kfs buffer). The overprinting of Stage 2 assemblages on portions of Stage 1 locally produces complex textures within the lodes at True Hill. The composition of both Stage 1 and 2 assemblages in the lodes is controlled by the (i) host rock composition and (ii) the mineralizing hydrothermal fluids. The deposition of Sn and LREE from Stage 2 fluids formed cassiterite and monazite along the reaction front between Stage 2 assemblages and chlorite-sulfide (Stage 1) and granite. Deposition of cassiterite probably occurred in response to (i) an increase in the $\mathrm{Fe}-\mathrm{Cl}$ complexing at the expense of $\mathrm{Sn}$ - and $\mathrm{LREE}-\mathrm{Cl}$ complexes during interation with Stage 1 assemblages, (ii) an increase in $\mathrm{pH}$ due to the feldspar hydrolysis in the granite and (iii) cooling of the fluid by the host rock. Although uneconomic, tin-sulfide lodes at True Hill have similarities with lodes developed within the North Zone of Mount Pleasant (New Brunswick) and Cornwall (England). However, the association of hematite and phengite with cassiterite mineralization is unique to this deposit.
\end{abstract}

Le porphyre granitique subvolcanique de True Hill (Nouveau-Brunswick méridional) est lié par sa genèse au cortège granitique dévono-carbonifere de Beech Hill. Trois coupoles de porphyre granitique de True Hill (TH) altéré en greisen renferment des zones minéralisées en $\mathrm{Bi}-\mathrm{Sn}-\mathrm{Mo}-\mathrm{W}$ et qui montrent des similitudes avec les gisements voisins de W-Mo-Bi présents à Mount Pleasant (MP).

Des faisceaux filoniens porteurs d'étain $(0,03$ à $0,66 \%$ pds. Sn) s'installent le long de failles et de cassures recoupant les porphyres granitiques de True Hill, tant minéralisés que stériles, ainsi que leur encaissant métasédimentaire (Formation de Waweig). Au sein de ces faisceaux, et surtout du faisceau central principal, on note deux types de minéralisation: un assemblage précoce à chlorite-sulfure (stage 1) et un assemblage tardif à hématite-phengite-cassitérite (stage 2) qui remplace en partie le premier. L'assemblage représentant le stage 1 consiste en de la septechlorite riche en $\mathrm{Fe}$, de la pyrite, de la blende pauvre en $\mathrm{Fe}$, de la magnétite, de la chalcopyrite, de la galène, des sulfures à $\mathrm{Pb}-\mathrm{Bi}$, de la tennantite, du mispickel et de l'argent natif. La métasomatose des Fe-Mg-Mn, dont provient la chloritisation, s'accompagne d'un lessivage des éléments alcalins et alcalinoterreux durant l'hydrolyse des feldspaths. L'assemblage dénotant le stage 1 (chlorite-sulfures) se forma à basse température $\left(<200^{\circ} \mathrm{C}\right)$ et faible fugacité d'oxygène. L'assemblage traduisant le stage 2 comporte de l'hématite, de la phengite, de la cassitérite, ainsi que de la monazite avec de faibles quantités de quartz et de fluorine tardifs. Cet assemblage fait intervenir des températures un peu plus élevées $\left(200^{\circ} \mathrm{C}\right.$ à $300^{\circ} \mathrm{C}$ ), une fugacité d'oxygène plus élevée (au-dessus du tampon hématite-magnétite) et des pH modérés (en-dessous du tampon des feldspaths potassiques de la muscovite). La surimpression des assemblages représentant

-Present Address: Department of Geology, University of Ottawa and Ottawa-Carleton

Geoscience Centre, Ottawa, Ontario K1N 6N5, Canada 
le stage 2 sur des portions du stage 1 produit localement des textures complexes au sein des faisceaux filoniens de True Hill. La composition des assemblages dénotant tant le stage 1 que le stage 2 au sein de ces faisceaux est régie par: (i) la composition de l'encaissant et (ii) les fluides minéralisateurs hydrothermaux. Le dépôt d'étain et de T.R. légères à partir des fluides du stage 2 engendra de la cassitérite et de la monazite le long du front réactionnel, entre les assemblages témoins du stage 2 les chloritesulfures et le granite. Le dépôt de la cassitérite est probablement le fruit de: (i) une augmentation de la formation de complexes à $\mathrm{Fe}-\mathrm{Cl}$ aux dépens des complexes à Sn et à Cl-T.R. légères durant l'interaction avec des assemblages du stage 1, (ii) une élévation du pH par suite de l'hydrolyse des feldspaths du granite, et (iii) le refroidissement du fluide par l'encaissant. Bien que de nature non économique, les faisceaux filoniens à étain et à sulfures présents à True Hill ne sont pas sans rappeler les faisceaux développés dans la Zone Nord de Mount Pleasant (Nouveau-Brunswick) et à Comwall (Angleterre). Cependant, ce gisement se singularise par l'association d'hématite et de phengite avec la minéralisation en cassitérite.

[Traduit par le journal]

\section{INTRODUCTION}

In southwestern New Brunswick several Sn-W-Mo deposits are genetically associated with Late Devonian to Early Mississippian peraluminous granites (Ruitenberg and Fyffe, 1982; Ruitenberg and McCutcheon, 1985). Of these the deposit at Mount Pleasant is the most well documented (Fig. 1). At Mount Pleasant W-Mo-Bi ore zones are associated with fine-grained granite that formed in a shallow, subvolcanic environment (Ruitenberg, 1963; Dagger, 1972; Parrish and Tully, 1978; Pouliot et al., 1978; Davis and Williams-Jones, 1985; Kooiman et al., 1986). Structurally-controlled cassiterite-sulfide lodes crosscut fine-grained granite and associated W-Mo-Bi mineralization in the North Zone and Fire Tower Zone at MP (Kooiman et al., 1986). They interpreted these lodes to be related to granite porphyry that intruded older fine-grained granite and associated W-Mo orebodies. Some sulfide-poor, cassiterite-rich zones are also associated with this younger granite. In the Fire Tower Zone (MP; Fig. 1), these zones are poorly defined but are associated with irregularly developed chlorite, topaz, fluorite, biotite alteration (Kooiman et al., 1986). In the North Zone, near-surface replacement deposits of cassiterite, stannite, pyrnhotite, pyrite, arsenopyrite, sphalerite, and chalcopyrite with quartz, fluorite and topaz have reserves of approximately 2500 tonnes with an average grade of $0.6 \mathrm{wt}$. \% $\mathrm{SnO}_{2}, 2.3 \mathrm{wt} . \% \mathrm{Zn}, 0.3 \mathrm{wt}$. \% Cu and 0.36 wt. \% Pb (Mulligan, 1975). Reserves in the Deep Tin Zone below the North Zone (MP) are approximately 2.14 million tonnes grading $0.45 \mathrm{wt} . \% \mathrm{SnO}_{2}, 0.8 \mathrm{wt} . \% \mathrm{Zn}$ and $0.06 \mathrm{wt} . \% \mathrm{~W}$ (Sinclair et al., 1988). Total reserves in the Deep Tin Zone, Contact Crest, Contact Flank and Endozone deposits in the North Zone at Mount Pleasant contain approximately 5.9 million tonnes of 0.79 wt. \% Sn (The Northern Miner, October 1985).

Located $4.5 \mathrm{~km}$ west of Mount Pleasant, the True Hill granite porphyry has intruded Silurian (?) metasedimentary rocks and locally metamorphosed them to biotite-andalusite-cordierite grade hornfelses (Figs. 2,3). The True Hill granite is petrographically and chemically similar to the Mount Pleasant fine-grained granite (Lentz et al., 1988). Endogranitic and exogranitic mineralized zones are associated with three exposed granite cupolas (TH; Fig. 1). Low grade Bi-Sn-Mo-W mineralized zones (TH), similar to the W-Mo-Bi orebodies at Mount Pleasant, are associated with greisen alteration in two of the three cupolas (Lentz et al., 1988). Cassiterite-sulfide lodes occur along faults that crosscut the True Hill granite and associated greisen.

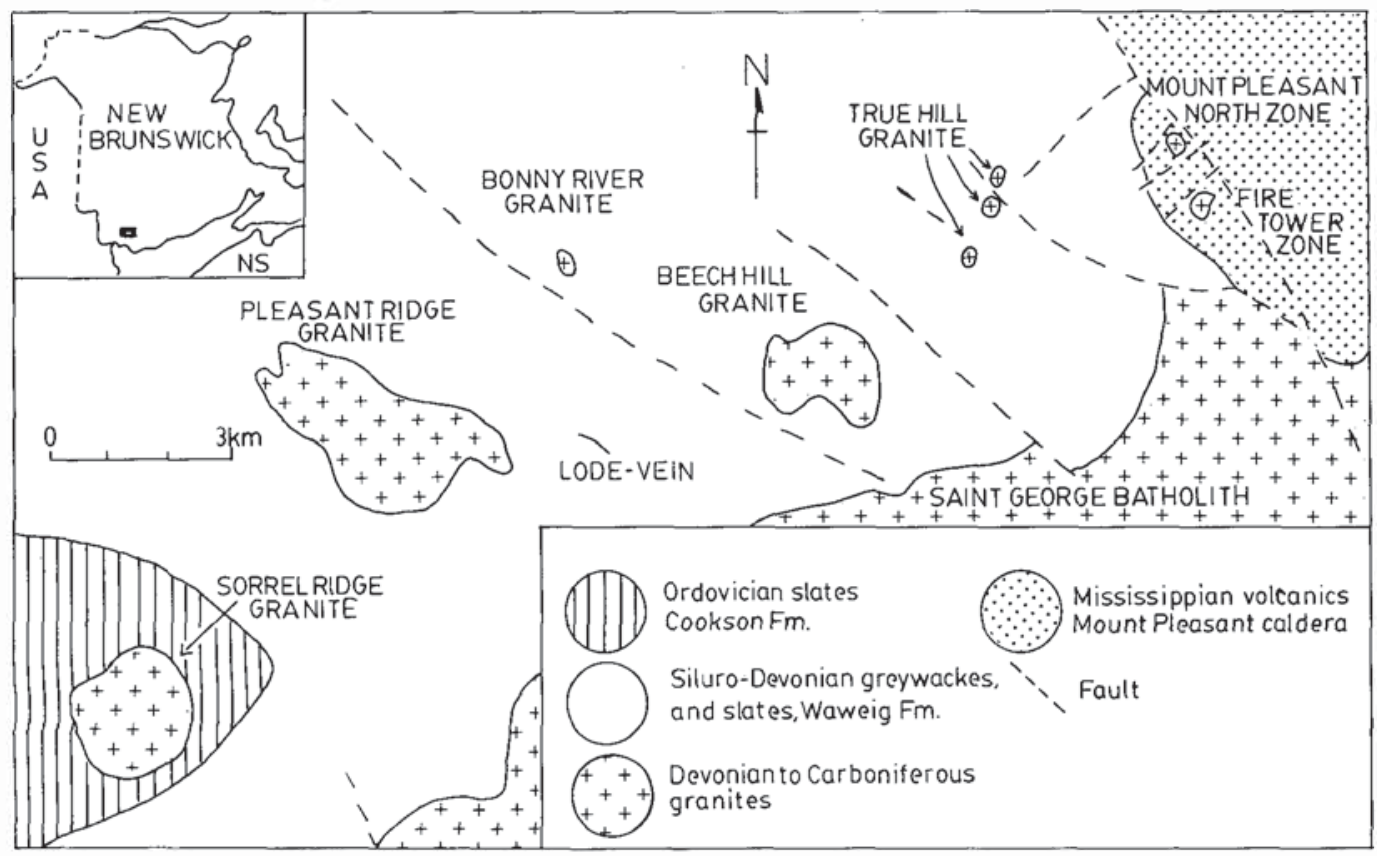

Fig. 1. Geological map of the Mount Pleasant area, southwestem New Brunswick (modified after Taylor et al., 1985). 


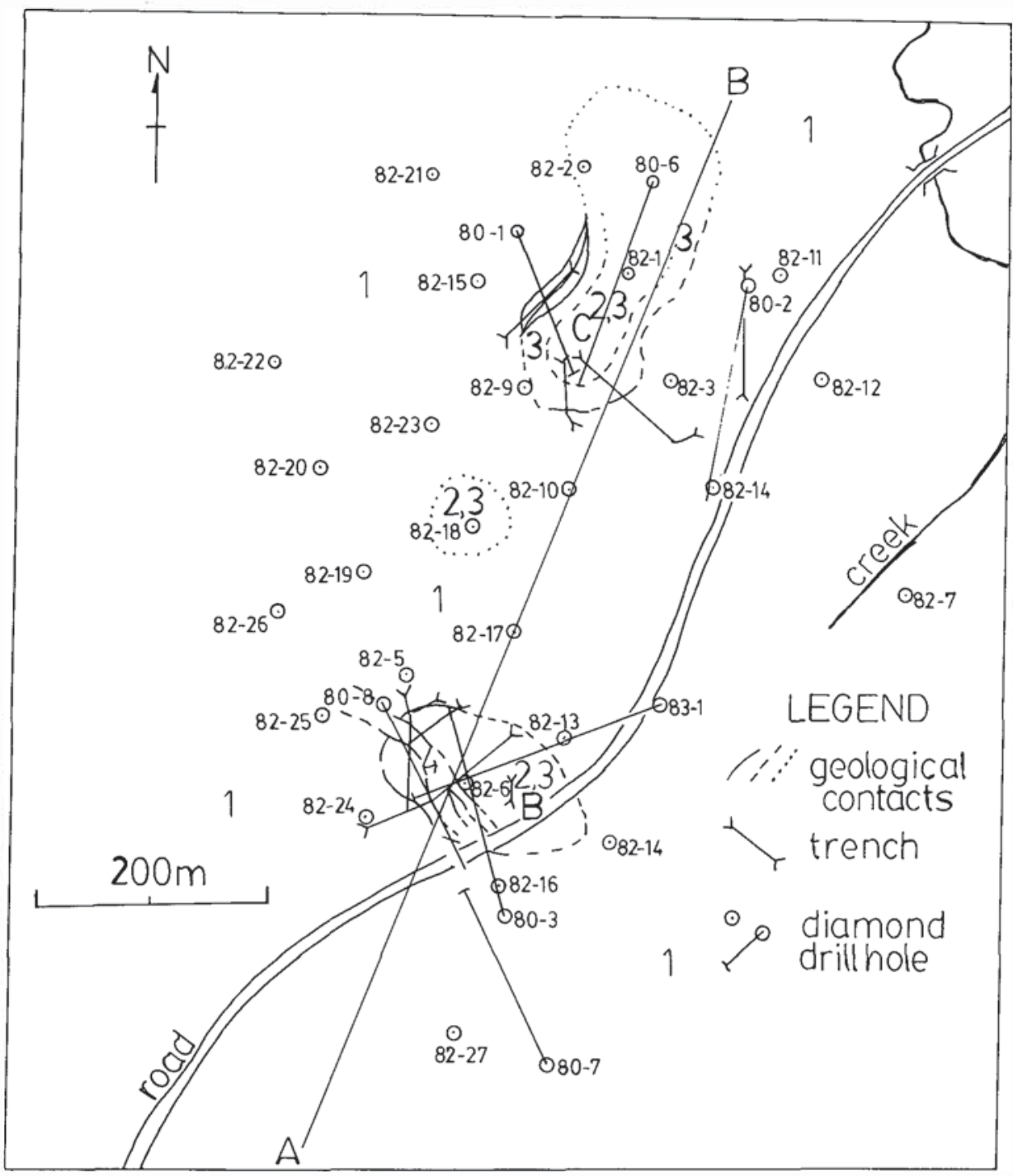

Fig. 2. True Hill geological map of cupolas B and C with locations of diamond drill hole (DDH) and trench locations: 1 - Metasedimentary rocks, 2 - Granite porphyry, 3 - Greisen, 4 - Tin-sulfide lodes. (A-B cross section see Fig. 3.)

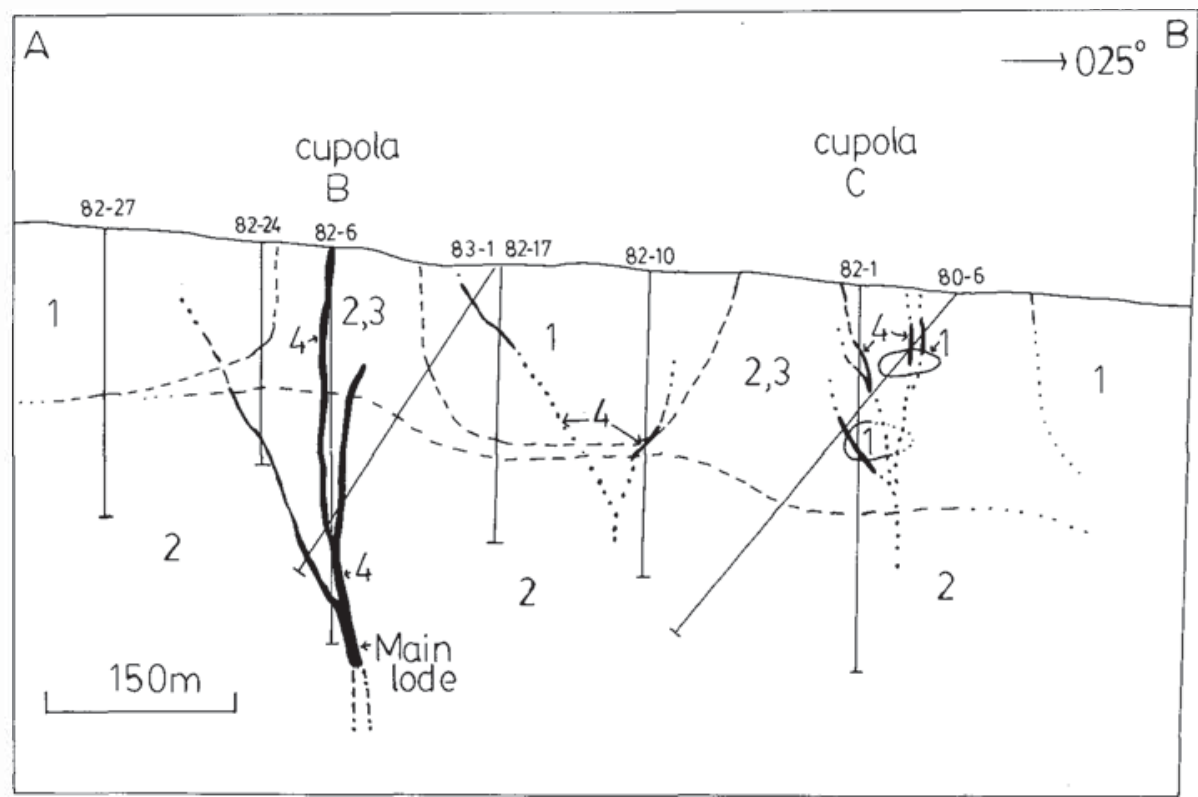

Fig. 3. True Hill geological cross section (A-B) of cupola B and C (see Fig. 2) with DDH locations. 
The purpose of this study is two-fold; to evaluate the relationship of lode mineralization at True Hill to earlier Bi-Sn-MoW greisen mineralized zones associated with the True Hill granite and to compare the tin lode mineralization of True Hill with the North Zone at Mount Pleasant. In addition, this study attempts to evaluate the mechanisms responsible for the transport and deposition of tin within the True Hill lode. The good geologic control of the Main lode provided by surface exposure and drill intersections, forms the basis for most of the petrographic and geochemical analyses.

\section{ANALYTICAL TECHNIQUES}

Ten samples of various types of mineralized lodes were analysed in duplicate by X-ray Assay Limited (Don Mills, Ontario) for major and trace elements. Analytical precision is $\pm 3 \%$ for major elements and $\pm 5 \%$ for trace elements having abundances three times their detection limit. A selected True Hill granite composition was obtained by averaging several analyses (Lentz et al., 1988).

The sulfur isotopes were determined on $\mathrm{SO}_{2}$ gas prepared by oxidizing pyrite with $\mathrm{Cu}_{2} \mathrm{O}$ at $1050^{\circ} \mathrm{C}$ for 15 minutes. Analyses were performed on the micromass $602 \mathrm{E}$ mass spectrometer (Derry Laboratory, University of Ottawa), calibrated with an internal sulfur standard. The analyses are expressed relative to the Canyon Diablo Troilite (CDT) and the accuracy and precision are $\pm 0.1 \delta^{34} \mathrm{~S}$ based on replicate analyses of the standard.

A Cambridge S4-10 stereoscan (SEM) was used for quantitative energy dispersive (SEM-EDS) analyses of minerals on carbon-coated polished thin sections at the University of New Brunswick. Both natural and synthetic sulfide and silicate standards were used to calibrate the EDAX system. Reliable analytical totals for chlorite were considered to be between 85 to $90 \mathrm{wt}$. \% due to the uncertainty in hydroxyl content of septechlorites and chlorites. Only one phengite analysis was considered reliable with a total within 2 wt. \% of 95 wt. \% (Table 1).
Sphalerite, cassiterite and nutile were renormalized to $100 \mathrm{wt} . \%$ if within $2 \mathrm{wt}$. \% for comparative purposes.

\section{GEOLOGY OF THE TRUE HILL AREA}

Three cupolas of True Hill granite porphyry designated A, B and $\mathrm{C}$ are exposed in outcrop and 36 drill holes (Figs. 2,3). The granite porphyry contains quartz (30-35 vol. \%), K-feldspar (2530 vol. \%), plagioclase (30 vol. \%) and biotite (5 vol. \%) phenocrysts with a compositionally similar matrix. Accessory minerals occurring with biotite are titanite, zircon, magnetite and ilmenite. Major-and trace-element whole-rock analyses indicate that the True Hill granite is highly fractionated (Lentz et al., 1988). Lentz et al., (1988) determined that the True Hill granite crystallized at approximately $100 \mathrm{MPa} \mathrm{P}_{\mathrm{H} 20}$ and between $700^{\circ}$ and $730^{\circ} \mathrm{C}$.

The Silurian (?), greenschist-grade, metagreywackes and slates of the Waweig Formation have upright open folds with undulatory northeast trending plunges. They are compositionally heterogeneous, containing variable proportions of sericite, chlorite, epidote, quartz, plagioclase, tourmaline, zircon, titanite, ilmenite and sulfides. Locally, biotite-cordierite-andalusite hornfels occur proximal to the intrusion. Compositional variation within the metasedimentary rocks precludes a detailed analysis of the major- and trace-element compositions of the metasediment-hosted lodes.

Bi-Sn-Mo-W greisen zones are located in cupolas B and C of the True Hill granite porphyry (Lentz et al., 1988). Three types of greisen alteration are present: (i) quartz-sericite, (ii) topazquartz-sericite and (iii) chlorite-quartz-sericite. Within the metasedimentary rocks, chlorite is more common with anatase and tourmaline. Commonly, greisen assemblages have associated fluorite, pyrite, magnetite, hematite, sphalerite, chalcopyrite, galena, bismuthinite, cassiterite, molybdenite and wolframite.

Table 1. Chemical composition of micas.

\begin{tabular}{lcccccccccc}
\hline wt. \% & 1 & 2 & 3 & 4 & 5 & 6 & 7 & 8 & 9 & 10 \\
\hline $\mathrm{SiO}_{2}$ & 23.8 & 24.6 & 23.3 & 22.1 & 23.0 & 22.1 & 21.8 & 22.2 & 22.0 & 47.3 \\
$\mathrm{Al}_{2} \mathrm{O}_{3}$ & 19.0 & 19.7 & 18.9 & 17.5 & 18.1 & 18.4 & 21.7 & 27.0 & 27.6 & 29.5 \\
$\mathrm{FeO}_{\mathrm{T}}$ & 35.9 & 38.2 & 39.4 & 40.5 & 33.0 & 32.9 & 43.0 & 35.8 & 34.4 & 4.91 \\
$\mathrm{MgO}$ & 2.47 & 2.35 & 2.73 & 2.23 & 3.55 & 3.28 & 1.32 & 1.0 & 4.7 & 0.23 \\
$\mathrm{MnO}$ & 4.11 & 3.06 & 3.02 & 3.06 & 8.82 & 8.75 & 1.22 & 0.4 & - & 0.21 \\
$\mathrm{CaO}$ & 0.00 & 0.00 & 0.10 & 0.00 & 0.00 & 0.00 & 0.07 & 1.3 & - & 0.09 \\
$\mathrm{Na}_{2} \mathrm{O}$ & 0.00 & 0.00 & 0.00 & 0.00 & 0.00 & 0.00 & 0.00 & - & - & 0.27 \\
$\mathrm{~K}_{2} \mathrm{O}$ & 0.00 & 0.00 & 0.00 & 0.06 & 0.00 & 0.00 & 0.08 & - & - & 10.5 \\
$\mathrm{Cr}_{2} \mathrm{O}_{3}$ & - & - & 0.00 & 0.17 & 0.00 & 0.00 & 0.10 & - & - & - \\
$\mathrm{NiO}_{\mathrm{Total}}$ & - & - & 0.11 & 0.00 & 0.00 & 0.00 & 0.00 & - & - & - \\
$\mathrm{T} .2$ & 88.7 & 87.6 & 85.6 & 86.4 & 85.4 & 89.3 & 89.1 & 89.2 & 93.0 \\
\hline
\end{tabular}

*Samples $1 @ 83-1-317.4$ m; 2,3,4@82-13-53.2 m; 5 and $6 @ 82-13-47.7$ m; $7 @ 80-5-78.4$ m, 8 from Mount Pleasant also includes 32.5 wt. \% $\mathrm{FeO}$ and 3.7 wt. \% $\mathrm{Fe}_{2} \mathrm{O}_{3}$ (Petruk, 1964); 9 has 30.2 wt. \% $\mathrm{FeO}$ and 4.7 wt. $\% \mathrm{Fe}_{2} \mathrm{O}_{3}$ from Cornwall, England (Petruk, 1964); 10 is phengite from Main lode 83-1-317.4 m. 


\section{GEOLOGY OF TIN LODES}

Tin lodes at True Hill comprise zones consisting of veins, veinlets and disseminated mineralization occurring along faults, fractures and/or foliations in metasedimentary rocks and granite porphyry. They are best developed in cupola B where the Main lode crosscuts greisenized granite porphyry near the surface and unaltered granite porphyry at depth (Figs. 2, 3,4,5A). The Main lode is $0.5 \mathrm{~m}$ to $3 \mathrm{~m}$ wide, has a strike length of at least $500 \mathrm{~m}$ and exceeds $300 \mathrm{~m}$ in depth. The Main lode is predominantly a replacement body that was controlled by a vertical fault and associated fracture zones in the granite porphyry. However, intense alteration has all but obliterated evidence of faulting except for the rare occurrence of silicified breccia within the Main lode. Linear magnetic anomalies are coincident with the Main lode but discontinuous along strike.

An early chlorite-sulfide assemblage (Stage 1) completely replaced granite and metasedimentary rocks and was subsequently overprinted by the Stage 2 hematite-phengite-cassiterite assemblage (Fig. 4). In some portions of the lode, Stage 2 fluids have partially replaced the chlorite-sulfide assemblage to produce a chlorite-bearing phengite-hematite-cassiterite assemblage. The irregular distribution of Stage 1 and 2 assemblages within samples of the lode produces complex chemical compositions. Cassiterite, introduced by the Stage 2 fluid, is deposited adjacent to recrystallized and altered chlorite-sulfide assemblages (Stage 1) and, to a lesser extent, unaltered granite (Fig. 4). No Snbearing phases have been identified in the chlorite-sulfide assemblage.

\section{Chlorite-Sulfide Assemblage (Stage 1)}

The chlorite-sulfide alteration consists dominantly of chlorite, with lesser amounts of sulfides and rare magnetite. XRD analysis revealed low intensity (001) reflections characteristic of poorly crystalline septechlorite. The (060) (1.56 to $1.60 \AA)$ reflection is indicative of high ferrous iron content (Carroll, 1970; Lentz, 1986). Analyses of 7 septechlorites from the metasediment-hosted lodes, indicate that they are iron-rich brunsvigite to ripidolite (Hey, 1954; Table 1). Analyses of chlorite from tin lodes at Mount Pleasant and Cornwall, England (Petruk, 1964) are similar to the True Hill chlorite analyses in having high ferrous Fe content ( 8 and 9 in Table 1). However, these chlorites have lower $\mathrm{SiO}_{2} / \mathrm{Al}_{2} \mathrm{O}_{3}$ ratios, and higher $\mathrm{MnO}$ contents than those of Mount Pleasant and Cornwall, England (Table 1).

Pyrite is the most common sulfide within the lodes. It is idiomorphic $(2-10 \mathrm{~mm})$ and usually evenly disseminated in a dominantly chloritic groundmass. Sphalerite is very common, occurring with galena, chalcopyrite, native silver, bismuth sulfides and pyrite, and typically contains abundant fine inclusions of chalcopyrite. Seven analyses of sphalerite from 3 localities have between 0.5 to $2 \mathrm{wt}$. \% Fe with minor $\mathrm{Cu}, \mathrm{Cd}$ and $\mathrm{Mn}$ (Table 2). Tennantite was identified in a metasediment-hosted lode where it is associated with pyrite and chalcopyrite. Galenobismutite and cosalite occur with sulfides in the Main lode and arsenopyrite $(0.2-0.05 \mathrm{~mm})$ was found in metasediment-hosted

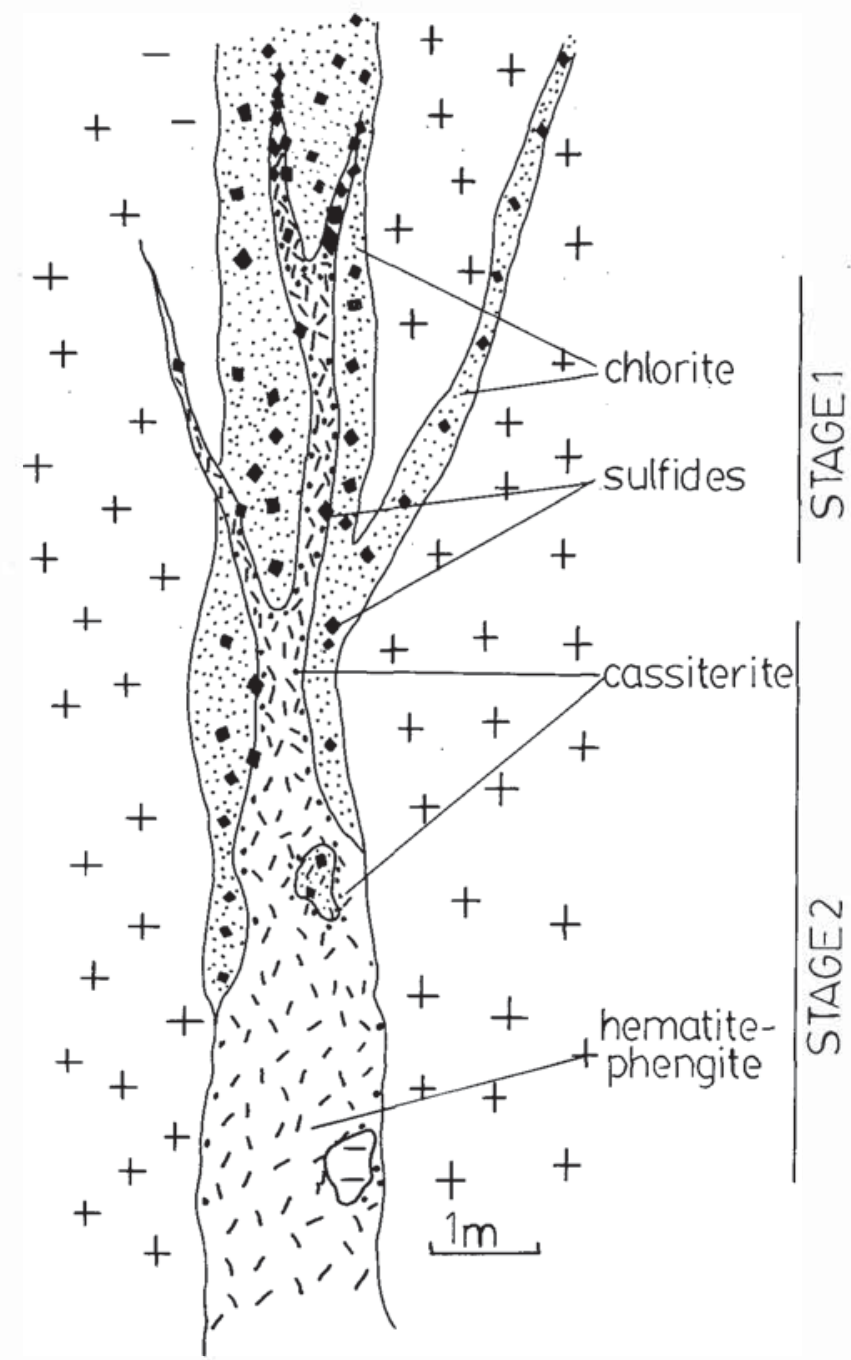

Fig. 4. Schematic section of a portion of the Main lode at True Hill illustrating the relationship between the chlorite-sulfide lode (Stage 1), the cassiterite-hematite-phengite lode (Stage 2), and the True Hill granite.

lodes. Native $\mathrm{Ag}(1-10 \mu \mathrm{m})$ is hosted within sphalerite, galena, pyrite and more rarely in chlorite. Magnetite $(0.2 \mathrm{~mm})$ is rare but occurs with pyrite and sphalerite as euhedral, finely disseminated grains (Fig. 5B). Rhodochrosite with a composition of $\left(\mathrm{Mn}_{0.83} \mathrm{Fe}_{0.07} \mathrm{Ca}_{0.05}\right) \mathrm{CO}_{3}$ occurs in a metasediment-hosted lode (Lentz, 1986).

\section{Hematite-Phengite-Cassiterite Assemblage (Stage 2)}

The second mineralizing episode (Stage 2) at True Hill consists of cassiterite with hematite and phengite. Phengite, specularite, quartz and fluorite are the predominant minerals of this assemblage. As with the chlorite-sulfide assemblage, brecciated host rocks are almost entirely replaced, except where silicification has locally preserved breccia within the Main lode. Cassiterite is weakly disseminated throughout the zone of hematite-phengite alteration with more abundant cassiterite near the chlorite-sulfide alteration.

The phengite is generally coarse grained ( 2 to $5 \mathrm{~mm}$ ) and occurs as radiating aggregates superimposed on early fine- 


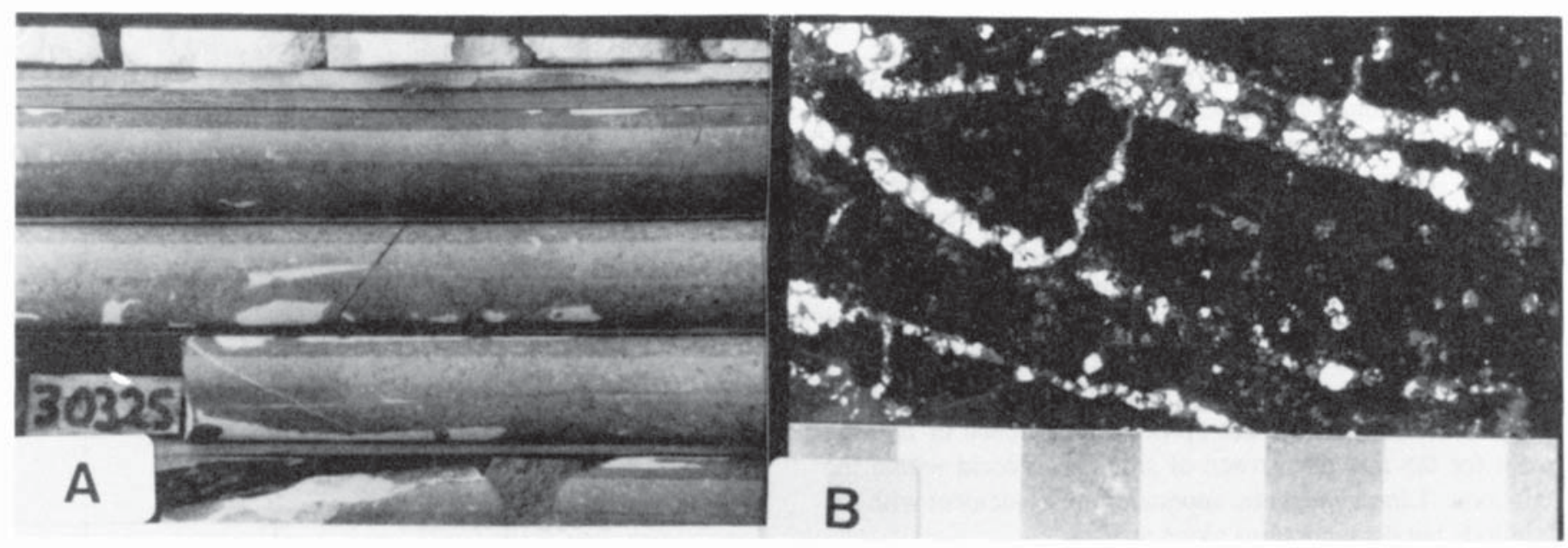

Fig. 5. (A) Unaltered True Hill granite porphyry beside Main lode (DDH 83-01-303 m; $13 \mathrm{~cm}$ across). (B) Stage 1 chlorite-magnetite lode (dark) veined by pyrite (light) which is inturn replaced by hematite (grey) (Stage 2; Trench 7, cupola C).

Table 2. Compositions of sphalerite.

\begin{tabular}{lccccccc}
\hline wt. \% & 1 & 2 & 3 & 4 & 5 & 6 & 7 \\
\hline $\mathrm{Zn}$ & 67.0 & 66.3 & 64.3 & 65.4 & 66.6 & 67.5 & 68.2 \\
$\mathrm{Fe}$ & 1.50 & 2.00 & 0.50 & 1.43 & 1.48 & 1.27 & 1.3 \\
$\mathrm{Cu}$ & 0.00 & 0.27 & 0.27 & 0.34 & 0.00 & 0.31 & 0.84 \\
$\mathrm{Cd}$ & 0.31 & 0.27 & 0.44 & 0.33 & 0.61 & - & - \\
$\mathrm{S}$ & 31.2 & 31.2 & 34.5 & 32.5 & 31.3 & 30.9 & 29.7 \\
Total & 100.0 & 100.0 & 100.0 & 100.0 & 100.0 & 100.0 & 100.0 \\
\hline
\end{tabular}

*1 - rim; 2 - core of sphalerite $(82-13-53.2 \mathrm{~m}) ; 3$ - $(82-24-162 \mathrm{~m}) ; 4$ to 7 - $(80-15$ -

$38.1 \mathrm{~m})$. Renormalized samples within $2 \%$ of $100 \%$.

grained chlorite (Figs. 6A, B, D, 7A, B, C). A single analysis of phengite from the Main lode is presented in Table 1. Two samples have a d $(001)$ spacing of $9.8 \AA$ which is characteristic of Fe-rich muscovites and phengites. In addition, the micas are transitional between the $1 \mathrm{M}$ and $2 \mathrm{M}$ polytypes. Carroll (1970) found the transition from the $1 \mathrm{M}$ to $2 \mathrm{M}$ Fe muscovite to occur between $200^{\circ}$ and $300^{\circ} \mathrm{C}$.

Specularite is fine to medium grained $(<0.1 \mathrm{~mm})$ and commonly pseudomorphs and/or replaces pre-existing sulfides (Figs. $6 \mathrm{~A}, \mathrm{D}, \mathrm{E}, 7 \mathrm{~A}, \mathrm{~B}, \mathrm{D})$. Fluorite and quartz occurs mainly in the interstices of phengite and along reaction margins adjacent to the chlorite-sulfide assemblage (Fig. 6D). Medium- to fine-grained hydrothermal quartz is minor and is variably present in portions of the Main lode. Fluorite is most closely associated with the metasediment-hosted lodes due to the high $\mathrm{CaO}$ content which favours the deposition of fluorite.

Schorl occurs as very fine- to coarse-grained acicular crystals with chlorite in altered metasedimentary rocks. Coarsegrained, dark blue-green, zoned schorl forms acicular splays with quartz, phengite, rutile and cassiterite. However, boron was not found in the few samples analysed. Rutile is common in lodes hosted by metasedimentary rocks and was formed by oxidation of Ti-rich biotite and ilmenite. Cassiterite mantles fine-grained, euhedral rutile (Fig. 7F). Rutile contains $1.3 \mathrm{wt} . \% \mathrm{SnO}_{2}$ and 5.4 wt. $\% \mathrm{Fe}_{2} \mathrm{O}_{3} \mathrm{~T}$ (Table 3). At Mount Pleasant, rutile and cassiterite are hosted within greisenized porphyry (Petruk, 1964, 1973; Dagger, 1972; Pouliot et al., 1978).

Cassiterite is predominantly concentrated along the reaction

Fig. 6. (A) Disseminated magnetite (mt) + (pyrite (py)), galena (gn), and sphalerite (sph) in chlorite matrix (chlorite-sulfide assemblage) being replaced by hematite (hem) and phengite (phg) (S.E.M photo; DDH 80-3-315 ft.). (B) Phengite (phg) replacing chlorite (chl) during interaction of the later (hematite-phengite) fluid with the pre-existing chlorite-sulfide assemblage (DDH 83-1-317.4 m). (C) Remobilized pyrite (py) enclosing sphalerite (sph) in a quartz (qtz) matrix related to hematite-phengite assemblage (S.E.M. photo; DDH 83-1-289.5 m). (D) Fluorite(fl), phengite (phg), and hematite (hem) replacing chlorite (chl) from pre-existing chlorite-sulfide assemblage (S.E.M. photo; DDH 80-3-350 ft.). (E) Hematite (hem) replacing pyrite (py) with monazite (mon) and hosted in phengite (S.E.M. photo; Cupola C Trench 7b). (F) Rutile (rt) mantled by cassiterite (cass) in hematite-phengite and tourmaline-rich metasediment-hosted lode (S.E.M. photo; DDH 80-5-561 ft.). 


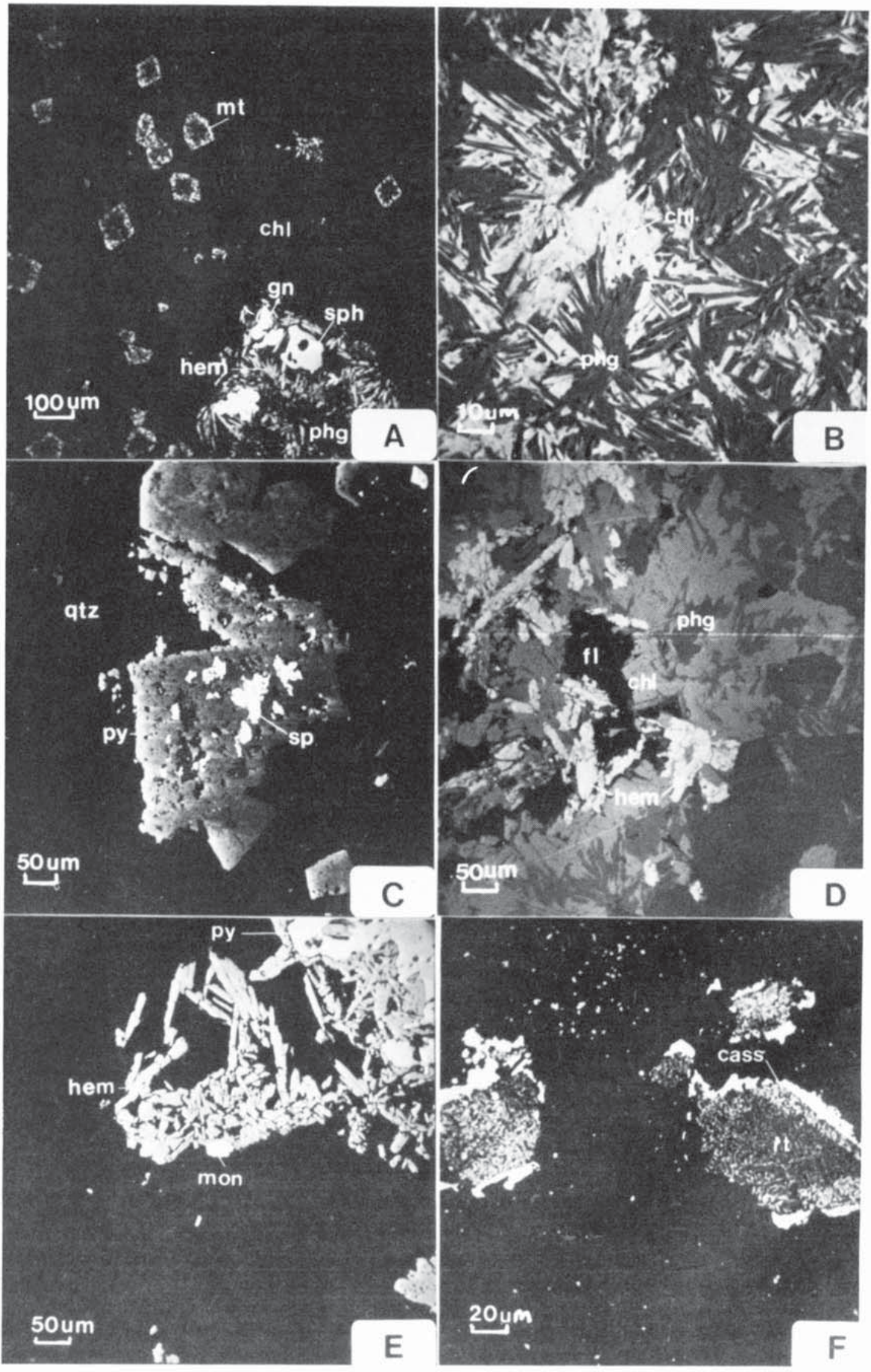




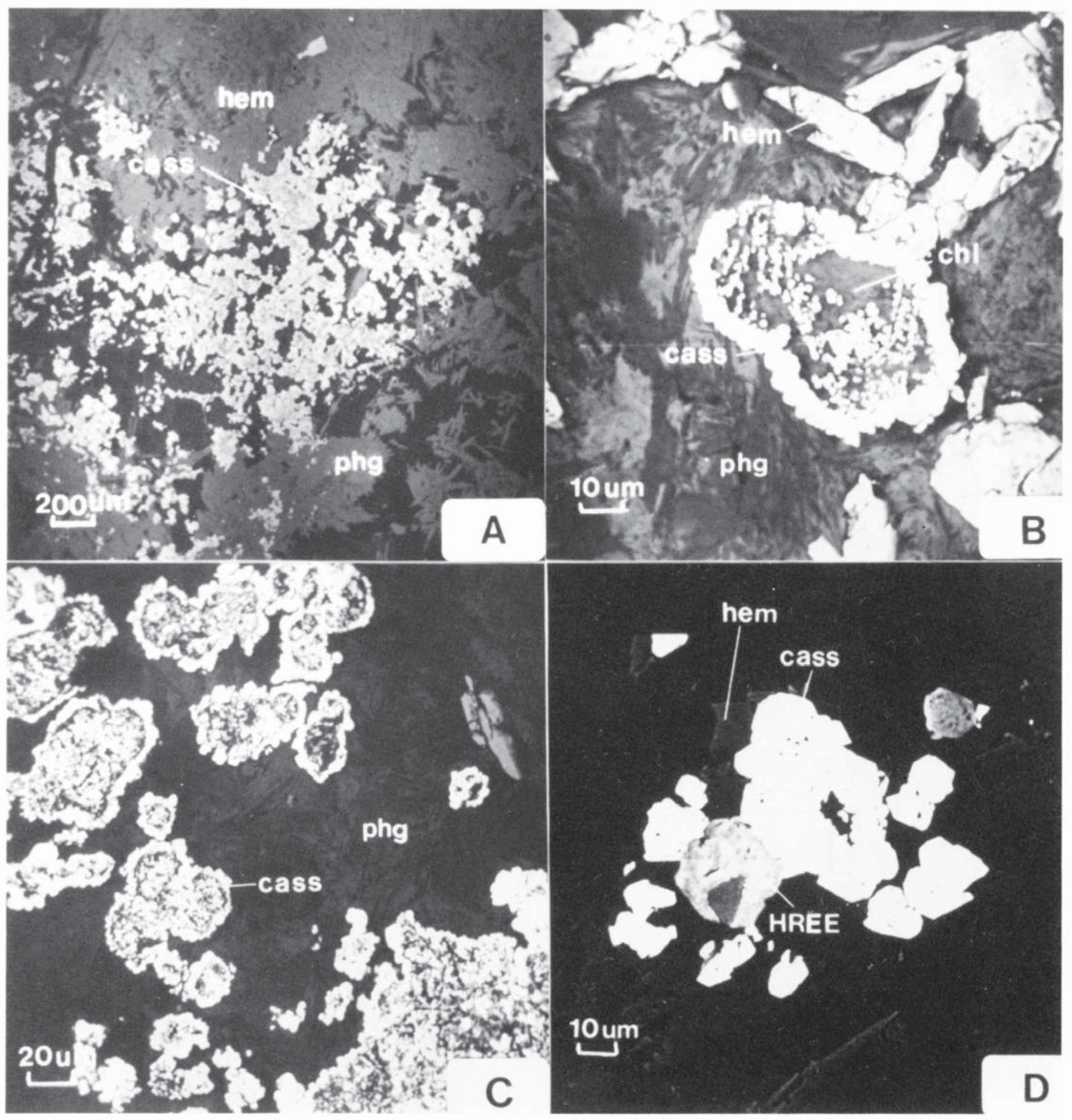

Fig. 7. (A) Cassiterite (cass) hosted in hematite (hem) and phengite (phg) (S.E.M. photo; DDH 83-1-316.5 m). (B) Cassiterite (cass) with chlorite (chl) in hematite (hem) and phengite (phg) assemblage (S.E.M. photo; 83-1-284 m). (C)Cassiterite (cass) mantling cassiterite crystals and coalescing to form glomeroporphyritic crystals in phengite (phg)(S.E.M. photo; DDH 83-1-284 m). (D) HREE-phosphate mineral (xenotime?) associated with hematite (hem), phengite (dark) and cassiterite (cass) assemblage (S.E.M. photo; DDH 83-1-290.9 m).

front between Stage 1 and 2 alteration, where it occurs as finely disseminated colliform crystals, in places coalescing to form dense aggregates (Fig. 7A, B). Metasediment-hosted cassiterite has higher $\mathrm{TiO}_{2}(3.0 \mathrm{wt}$. \%) and lower $\mathrm{Fe}$ whereas a granitehosted cassiterite from the Main lode has only $0.9 \mathrm{wt} . \% \mathrm{TiO}_{2}$ and higher Fe indicative of the low Ti content of the granite (Table 3).
Other trace minerals associated with the second stage of mineralization include monazite (Fig. 6E) and a HREE phosphate mineral (xenotime?; Fig. 7D). Both of these minerals commonly occur with cassiterite in most portions of the lodes and are also concentrated along the reaction margin. 
Table 3. Compositions of rutile and cassiterite.

\begin{tabular}{lccc}
\hline wt. \% & 1 & 2 & 3 \\
\hline $\mathrm{SnO}_{2}$ & 97.0 & 96.5 & 1.30 \\
$\mathrm{TiO}_{2}$ & 2.98 & 0.90 & 93.8 \\
$\mathrm{Fe}_{2} \mathrm{O}_{3}$ & 0.00 & 2.27 & 4.89 \\
$\mathrm{MnO}$ & 0.00 & 0.24 & - \\
Total & 100.0 & 100.0 & 100.0 \\
\hline
\end{tabular}

*1 - Cassiterite (metasediment-hosted with rutile; Fig. 6F; 80-5-561 ft); 2 - Cassiterite (granite-hosted with hematite-phengite; 83-1$284 \mathrm{~m}$ ); 3 - Rutile (metasediment-hosted mantled by cassiterite; Fig. 6F; 80-5-561 ft).

\section{Remobilization Textures}

It is evident that fracturing precedes Stage 2 and postdates Stage 1 mineralization (Fig. 5B); hence, two discrete mineralizing episodes are indicated. The boundary between the two stages may be sharp (near surface) to diffuse (at depth) depending on the extent of chemical interaction. This "reaction front" is represented by an irregular zone with variably replaced chloritesulfide assemblages (Fig. 6A, B, C, D). Complex textural features were formed by the alteration of the Stage 1 assemblage to the Stage 2 assemblage. Septechlorites, for instance, increase in grain size with increasing proximity to Stage 2 assemblages (Fig. 6B) and they approach an equilibrium $14 \AA$-chlorite structure (increase 001 reflection) at temperatures $>200^{\circ} \mathrm{C}$. Chlorite has been identified as part of the hematite-phengite assemblage in areas of considerable reaction with the chlorite-sulfide assemblage and may represent a stable phase.

There is abundant textural evidence for alteration and replacement of septechlorite and sulfides (reaction rims, coronas, embayments) during Stage 2 mineralization along the reaction front between the two assemblages (Figs. 5B, 6A, C, E). In some areas, pyrite has apparently been remobilized (dissolved and redeposited) by Stage 2 fluids, as indicated by coarse grains of pyrite in fractured chlorite-magnetite lode (Fig. 5B) or hosted in silicified lode. Commonly it is subsequently replaced by hematite during desulfidation (Fig. 5B) and hematite often replaces pyrite (Fig. 6E).

\section{GEOCHEMISTRY OF LODES}

Mineralogical differences between Stage 1 chlorite-sulfide and Stage 2 hematite-phengite-cassiterite assemblages are reflected by major chemical differences between the two types of mineralization (Table 4).

The major- and trace-element composition of the lodes reflect the dominant minerals in each type. Identification of the distinguishing chemical characteristics between the two types of mineralization is problematic because samples analyzed include variable proportions of the chlorite-sulfide and hematite-phengite-cassiterite assemblage. Only sample 34 (metasedimenthosted) represents Stage 1 assemblages and sample 24 represents Stage 2 assemblages (granite-hosted). The remaining samples have both Stage 1 and 2 assemblages. Chemical analyses illustrated in Figures 8,9 and 10 result from the combined effects of the two assemblages; thus, subsequent discussion will try to emphasize the individual roles of each type of mineralization.

Within the granite-hosted lode samples, minor volume increases are expected due to hydration and have densities between 2.85 and $3.68 \mathrm{~g} / \mathrm{cm}^{3}$ in comparison to the granite $\left(2.54 \mathrm{~g} / \mathrm{cm}^{3}\right)$. In addition, the most immobile elements (e.g., $\mathrm{TiO}_{2}$ ) are mobile (enriched slightly) even after accounting for density increases. Lentz et al. (1988) reported that $\mathrm{TiO}_{2}$ varied from 0.07 to 0.11 wt. $\%$ which is within the $0.08 \mathrm{wt} . \% \mathrm{TiO}_{2}$ from the average True Hill granite (Table 4). This is similar to the $\mathrm{TiO}_{2}$ variation in the 7 granite-hosted lodes $(0.05$ to $0.15 \mathrm{wt}$. \%) hence a rigorous mass balance analysis is not warranted but comparative analysis with the unaltered granite should be examined with caution.

\section{Composition of Chlorite-Sulfide Assemblage (Stage 1)}

The depletion of $\mathrm{Si}, \mathrm{K}, \mathrm{Na}, \mathrm{Ca}, \mathrm{Rb}$ and $\mathrm{Sr}$ and enrichment of $\mathrm{Fe}, \mathrm{Mg}$ and $\mathrm{Mn}$ in the granite-hosted lode (Figs. 8, 9; Table 4) is due to the chloritization of feldspars during hydrothermal alteration. The minor depletion of other trace elements ( $\mathrm{Th}, \mathrm{U}, \mathrm{Nb}, \mathrm{Ta}$, $\mathrm{Zr}$ and $\mathrm{Y}$ ) is probably produced at this stage as well. The strong enrichment in $\mathrm{S}, \mathrm{Cu}, \mathrm{Zn}, \mathrm{Cd}$, and $\mathrm{Bi}$ and moderate enrichment of $\mathrm{Pb}, \mathrm{Ag}$ and $\mathrm{Mn}$ relative to the True Hill granite (Fig. 9) is consistent with the presence of sulfide established by petrographic observations.

\section{Composition of Hematite-Phengite-Cassiterite Assemblage (Stage 2)}

The hematite-phengite-cassiterite assemblage is formed by alkali and hydrogen metasomatism coincident with oxidation of iron based on petrographic observation. The variation in the amount of $\mathrm{Fe}_{2} \mathrm{O}_{3} \mathrm{~T}, \mathrm{MgO}$ and $\mathrm{MnO}$ versus $\mathrm{K}_{2} \mathrm{O}$ and $\mathrm{Na}_{2} \mathrm{O}$ (Table 4) reflects the relative abundance of the two types of assemblages. The enrichment of alkali elements (Cs, $\mathrm{Rb}, \mathrm{Ba}$ and $\mathrm{K}$ ) in pre-existing depleted chloritized lode resulted in only moderate element depletions when the data are normalized to the average True Hill granite (Fig. 8).

\section{Rare-Earth-Element Compositions of the Lodes}

Of the ten mineralized samples analysed, three are hosted in metasedimentary rocks and the remainder in granite (Table 4). Chondrite-normalized (CN) REE abundances (Wakita et al., 1971) have a range of distributions (Fig. 10); $(\mathrm{La} / \mathrm{Lu})_{\mathrm{CN}}$ ranges from 0.7 to 8.2, of which $8.2,7.0$ and 6.4 correspond to the metasediment-hosted lodes. The granite-hosted lodes have a more restricted REE distribution in the highly fractionated True Hill granite (Lentz et al., 1988). The consistently higher $\mathrm{Eu}_{\mathrm{CN}}$ content in the metasediment-hosted lode is indicated by values of $\mathrm{Eu}_{\mathrm{CN}}$ of $20.5,27.4$ and 35.6 whereas the granite-hosted lodes 
Table 4. Chemical analyses of selected True Hill granite and lodes.

\begin{tabular}{|c|c|c|c|c|c|c|c|c|c|c|c|}
\hline $\begin{array}{l}\text { Sample } \\
\text { wt. \% }\end{array}$ & $\begin{array}{r}\text { TH } \\
\mathrm{G}\end{array}$ & $\begin{array}{l}20 \\
\text { LG }\end{array}$ & $\begin{array}{l}24 \\
\text { LG }\end{array}$ & $\begin{array}{l}26 \\
\text { LG }\end{array}$ & $\begin{array}{l}30 \\
\text { LG }\end{array}$ & $\begin{array}{l}32 \\
\text { LG }\end{array}$ & $\begin{array}{l}36 \\
\text { LG }\end{array}$ & $\begin{array}{l}38 \\
\text { LG }\end{array}$ & $\begin{array}{l}22 \\
\text { LS }\end{array}$ & $\begin{array}{l}28 \\
\text { LS }\end{array}$ & $\begin{array}{r}34 \\
\text { LS }\end{array}$ \\
\hline $\mathrm{g} / \mathrm{cm}^{3}$ & 2.54 & 2.85 & 3.35 & 3.09 & 3.68 & 2.97 & 3.37 & 3.32 & 3.16 & 3.33 & 3.13 \\
\hline $\mathrm{SiO}_{2}$ & 76.6 & 30.1 & 32.9 & 49.1 & 20.2 & 48.4 & 20.6 & 32.5 & 42.3 & 22.5 & 37.5 \\
\hline $\mathrm{TiO}_{2}$ & 0.08 & 0.08 & 0.05 & 0.11 & 0.15 & 0.10 & 0.08 & 0.09 & 0.96 & 1.01 & 1.39 \\
\hline $\mathrm{Al}_{2} \mathrm{O}_{3}$ & 12.82 & 6.24 & 9.96 & 14.65 & 13.15 & 14.0 & 17.5 & 15.4 & 14.9 & 18.15 & 11.65 \\
\hline $\mathrm{Fe}_{2} \mathrm{O}_{3}$ & 1.05 & 44.65 & 48.9 & 27.35 & 59.35 & 25.7 & 50.45 & 41.8 & 32.6 & 45.75 & 22.2 \\
\hline $\mathrm{MgO}$ & 0.09 & 0.13 & 0.21 & 0.18 & 0.35 & 0.705 & $\begin{array}{ll}5 & 0.69\end{array}$ & 0.57 & 0.84 & 1.77 & 1.56 \\
\hline $\mathrm{MnO}$ & 0.05 & 0.87 & 0.65 & 0.55 & 0.36 & 0.61 & 2.51 & 0.25 & 0.64 & 1.56 & 0.48 \\
\hline $\mathrm{CaO}$ & 0.61 & 0.19 & 0.06 & 0.12 & 0.09 & 0.33 & 0.05 & 0.01 & 0.19 & 1.38 & 0.84 \\
\hline $\mathrm{Na}_{2} \mathrm{O}$ & 3.39 & 0.04 & 0.06 & 0.08 & 0.08 & 0.08 & 0.02 & 0.08 & 0.04 & 0.06 & 0.01 \\
\hline $\mathrm{K}_{2} \mathrm{O}$ & 5.29 & 2.10 & 4.42 & 4.89 & 4.26 & 6.67 & 1.20 & 5.91 & 2.10 & 2.45 & 1.58 \\
\hline $\mathrm{P}_{2} \mathrm{O}_{5}$ & 0.01 & 0.02 & 0.01 & 0.02 & 0.03 & 0.03 & 0.03 & 0.03 & 0.02 & 0.03 & 0.03 \\
\hline LOI & - & 15.2 & 2.00 & 2.77 & 1.81 & 2.59 & 6.89 & 2.85 & 15.2 & 4.39 & 7.08 \\
\hline Total & 100. & 99.6 & 99.2 & 100.1 & 99.8 & 99.2 & 100.1 & 99.5 & 99.5 & 99.0 & 84.25 \\
\hline \multicolumn{12}{|l|}{ ppm } \\
\hline $\mathrm{Cr}$ & 2 & 20 & 10 & $<10$ & 10 & $<10$ & 15 & $<10$ & 20 & 90 & 130 \\
\hline $\mathrm{Rb}$ & 534 & 300 & 440 & 760 & 645 & 700 & 150 & 845 & 300 & 270 & 185 \\
\hline Sr & 26 & $<10$ & $<10$ & $<10$ & 10 & 10 & 10 & $<10$ & $<10$ & 10 & 10 \\
\hline Y & 83 & 140 & $<10$ & 130 & 55 & 155 & 20 & 55 & 140 & 35 & 10 \\
\hline $\mathrm{Zr}$ & 145 & 25 & 15 & 130 & 150 & 125 & 60 & 35 & 25 & 125 & 175 \\
\hline $\mathrm{Nb}$ & 100 & 55 & 20 & 50 & 80 & 35 & 75 & 30 & 55 & 80 & 90 \\
\hline $\mathrm{Ag}$ & 0.5 & 3.5 & 5.75 & 780 & 2.0 & 1.0 & 61 & 1.0 & 4.8 & 2.0 & 61 \\
\hline As & - & 2700 & 5 & 41.5 & 6 & 36.5 & 110 & 62 & 2700 & 3.5 & 375 \\
\hline Auppb & - & 80 & $<20$ & $<20$ & $<20$ & $<20$ & $<20$ & $<20$ & 80 & $<20$ & $<20$ \\
\hline $\mathrm{Ba}$ & 86 & 400 & $<150$ & 300 & 200 & $200<$ & $<150$ & 200 & 400 & $<150$ & 450 \\
\hline $\mathrm{Bi}$ & 1.5 & 720 & 100 & 86.0 & 40.5 & 15.0 & 3.45 & 11.5 & 720 & 13.5 & 435 \\
\hline $\mathrm{Cd}$ & 0.2 & 3.9 & 0.70 & $<0.2$ & 0.7 & 0.7 & $<0.2$ & 0.4 & 3.9 & 1.7 & 350.0 \\
\hline Co & 44 & 53 & 24 & 19 & 11 & 12 & 17 & 10 & 53 & 24 & 85 \\
\hline $\mathrm{Cr}$ & 2 & $<10$ & 4 & 110 & 9 & 2 & 2 & 3.5 & $<10$ & 110 & 155 \\
\hline Cs & 6.1 & 20 & 22.5 & 37.5 & 29.5 & 32.0 & 7.9 & 38 & 20 & 27.5 & 22.0 \\
\hline $\mathrm{Cu}$ & 8 & 130 & 40.5 & 25.5 & 405 & 10.0 & 74.0 & 8.25 & 130 & 210 & 2350 \\
\hline $\mathrm{Hg}$ & - & 3.5 & 2 & 6 & 8.5 & 6 & 6 & 4 & 3.5 & 5 & 9.5 \\
\hline Mo & 5 & 50 & 12 & $<5$ & 13.5 & $<5$ & 43 & 6 & 50 & 13 & 67 \\
\hline $\mathrm{Ni}$ & - & $<1$ & $<1$ & $<1$ & $<1$ & $<1$ & $<1$ & $<1$ & $<1$ & 22.5 & 91.5 \\
\hline $\mathrm{Pb}$ & 84 & 1300 & 155 & 70 & 6102 & 22450 & 185 & 35 & 395 & $730 \quad 2$ & 22450 \\
\hline $\mathrm{Sb}$ & 0.25 & 30.0 & 3.15 & 6.05 & 3.2 & 2.0 & 1.25 & 2.2 & 30.0 & 1.3 & 13.5 \\
\hline $\mathrm{Se}$ & - & 5 & $<3$ & $<3$ & $<3$ & $<3$ & $<3$ & $<3$ & 5 & $<3$. & 56 \\
\hline $\mathrm{Ta}$ & 10 & 3.5 & 2 & 6.5 & 9.5 & 3 & 8 & 4 & 3.5 & 2 & 1 \\
\hline $\mathrm{Zn}$ & 61 & 1050 & 365 & 245 & 320 & 425 & 1600 & $200 \quad 1$ & 1050 & 15505 & 59950 \\
\hline $\mathrm{Sc}$ & 3.95 & 4.35 & 4.95 & 2.35 & 6.2 & 3.35 & 7.7 & 6.3 & 4.35 & 11.5 & 19.5 \\
\hline $\mathrm{La}$ & 44.25 & 229 & 15.15 & 33.5 & 126 & 38.75 & 26.3 & 50.25 & 229 & 81 & 89.0 \\
\hline $\mathrm{Ce}$ & 103.5 & 428 & 46 & 105.5 & 251 & 92.5 & 57 & 108 & 428 & 155 & 170 \\
\hline Nd & 30 & 135 & 20 & 50 & 80 & 20 & 20 & 30 & 135 & 65 & 55 \\
\hline $\mathrm{Sm}$ & 10.0 & 37.4 & 8.0 & 17.9 & 16.5 & 9.25 & 6.15 & 8.5 & 37.4 & 12.65 & 12.95 \\
\hline Eu & 0.2 & 0.5 & 0.2 & 0.25 & 0.3 & 0.2 & 0.95 & 0.35 & 0.5 & 2.0 & 2.65 \\
\hline $\mathrm{Yb}$ & 23 & 32 & 6 & 24.5 & 17 & 34 & 10 & 10 & 32 & 7.5 & 8.5 \\
\hline Lu & 3.8 & 4.66 & 1.24 & 3.83 & 2.79 & 5.34 & 1.59 & 1.64 & 4.66 & 1.15 & 1.42 \\
\hline U & 32 & 13.5 & 30.75 & 24.6 & 38.5 & 24.3 & 12.0 & 19.5 & 13.5 & 6.2 & 5.5 \\
\hline Th & 69.6 & 24.0 & 6.75 & 47.0 & 74.5 & 77.0 & 41.0 & 28.0 & 24.0 & 47.0 & 25.5 \\
\hline B & - & 10 & $<10$ & $<10$ & $<10$ & $<10$ & $<10$ & $<10$ & 10 & $<10$ & $<10$ \\
\hline $\mathrm{Cl}$ & - & $<50$ & $<50$ & $<50$ & $<50$ & $<50$ & $<50$ & $<50$ & $<50$ & $<50$ & $<50$ \\
\hline $\mathrm{F}$ & - & 1600 & 630 & 1700 & 1250 & 2750 & 860 & $1700 \quad 1$ & 1600 & 1700 & 7050 \\
\hline In & - & 8.0 & 10.0 & 8.0 & 17.5 & 14.5 & 11.0 & 12.5 & 8.0 & 8.0 & 24.0 \\
\hline $\mathrm{Li}$ & 34.5 & 49.5 & 73 & 90.5 & 56.5 & 155 & 275 & 91 & 49.5 & 90.5 & 255 \\
\hline $\mathrm{S} \%$ & - & 16.6 & 0.05 & 0.485 & 0.06 & 0.575 & $5 \quad 1.58$ & 0.485 & $5 \quad 16.6$ & 0.485 & $5 \quad 5.02$ \\
\hline Sn & 6.8 & 6600 & 970 & 780 & 230 & 550 & 2300 & 49006 & 6600 & 780 & 1200 \\
\hline
\end{tabular}

* LG is granite-hosted lode, LS is metasediment-hosted lode. (X-ray Assay Laboratories Limited, 1885 Leslie Street, Don Mills, Ontario M3B 3J4). Majors elements, $\mathrm{Cl}$ and $\mathrm{S}$ (XRF), As, Au, Ba, Co, Cr, Cs, Hf, Mo, Sb, $\mathrm{Se}, \mathrm{Ta}, \mathrm{Sc}, \mathrm{La}, \mathrm{Ce}, \mathrm{Nd}, \mathrm{Sm}, \mathrm{Eu}, \mathrm{Yb}, \mathrm{Lu}, \mathrm{U}, \mathrm{Th}$ by INAA, Ag, Cd, Cu, Ni, Pb, Zn, B, In by D. C. Plasma spectrometry, $\mathrm{F}$ and $\mathrm{Li}$ by wet chem, and $\mathrm{Sn}$ by EMS. All duplicate analyses were within several percent of each other so were averaged. 


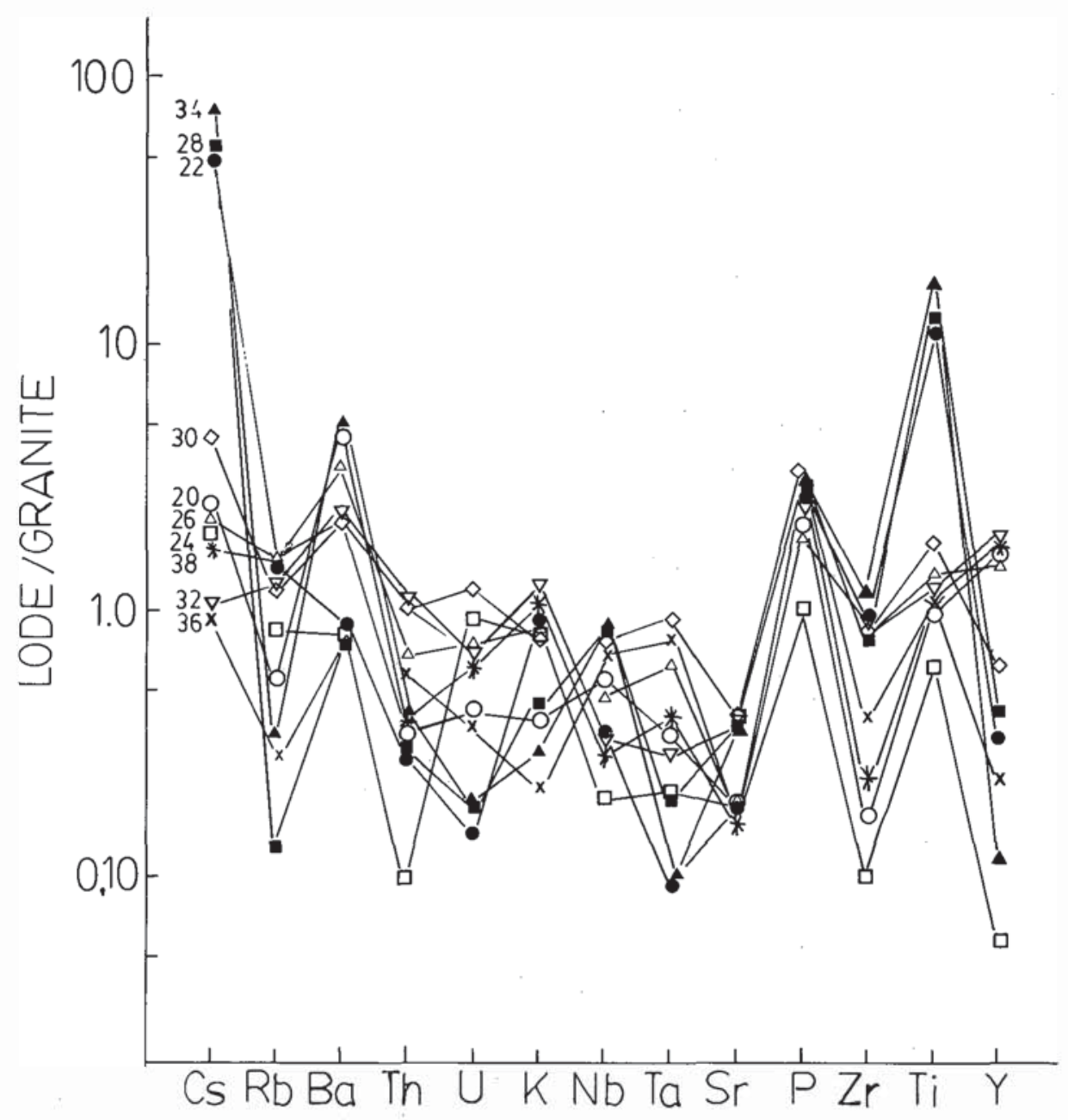

Fig. 8. Compositions of the lodes normalized to the "average" True Hill granite (Table 1). Elements are arranged according to their field strength.

range from 13.0 to $2.7 \mathrm{Eu}_{\mathrm{CN}}$. The high Eu content may, in part, be inherited from the metasediment during fluid interaction with metasedimentary rocks. This is substantiated by the strong positive correlation coefficients between $\mathrm{Eu}$ and $\mathrm{Cr}(0.96)$, $\mathrm{Ti}$ (0.96), and $\mathrm{Sc}(0.95)$. The Eu content of the granite-hosted lodes indicates an enrichment of 1 to 4.8 relative to the True Hill average granite (Fig. 10).

The absolute abundances of both LREE and HREE in the lodes are high; $\mathrm{La}$ and Lu concentrations being, respectively, 77 to 674 and 21 to 157 . To facilitate comparison with the granite, the absolute abundances of REE in the lode samples also have been normalized to True Hill granite (Table 4; Fig. 10). It is important to understand that in most cases, excluding a few relict zircons and rutile, REE-bearing minerals have not been identified in association with the Stage 1 assemblage. Only three of the seven granite-hosted lode samples are higher in LREE ( $\mathrm{La}, \mathrm{Ce}$, $\mathrm{Nd}$ and $\mathrm{Sm}$ ) as compared to the granite, whereas four are weakly to moderately lower than the granite (Fig. 10). The granitenormalized, low $\mathrm{Yb}$ and Lu (HREE) distribution indicates that the HREE have not been enriched in the lodes to the extent that the LREE have been enriched. Relative to the granite HREE, Yb and $\mathrm{Lu}$, range from 0.2 to 1.5 and 0.3 to 1.4 , respectively, and 4 of the 7 granite-hosted samples give results below the granite. The lode samples are variably enriched in LREE relative to the HREE with mean values of granite-normalized La, and Lu of 1.7 and 0.6 , respectively.

As previously mentioned, monazite commonly occurs with cassiterite in the hematite-phengite assemblage whereas xenotime occurs more rarely. This association explains the moderate positive correlation coefficients for $\mathrm{Sn}$ with $\mathrm{La}(0.65), \mathrm{Ce}(0.57)$, Nd (0.53), and $\mathrm{Sm}(0.58)$ respectively (above $90 \%$ confidence level) whereas correlation coefficients for $\mathrm{Sn}$ with $\mathrm{Yb}(0.23)$, and $\mathrm{Lu}(0.18)$ are positive but low (Lentz, 1986).

\section{Physiochemical Parameters}

Stage 1 hydrolysis of $\mathrm{K}$-feldspar to chlorite is estimated to occur at a pH between $5\left(200^{\circ} \mathrm{C}\right)$ and $6\left(100^{\circ} \mathrm{C}\right)$ at $\log \left(\mathrm{K}^{+}\right)=-1.5$ based on equilibria between chlorite and K-feldspar (Lentz, 1986). Similarly, Stage 2 is associated with the hydrolysis of Kfeldspar to muscovite (phengite) which occurs at a pH of 5.1 $\left(300^{\circ} \mathrm{C}\right.$ at $\log \left(\mathrm{K}^{+}\right)=-1$; Montoya and Hemley, 1975) and a protolysis alteration of chlorite to phengite (equation 1). 


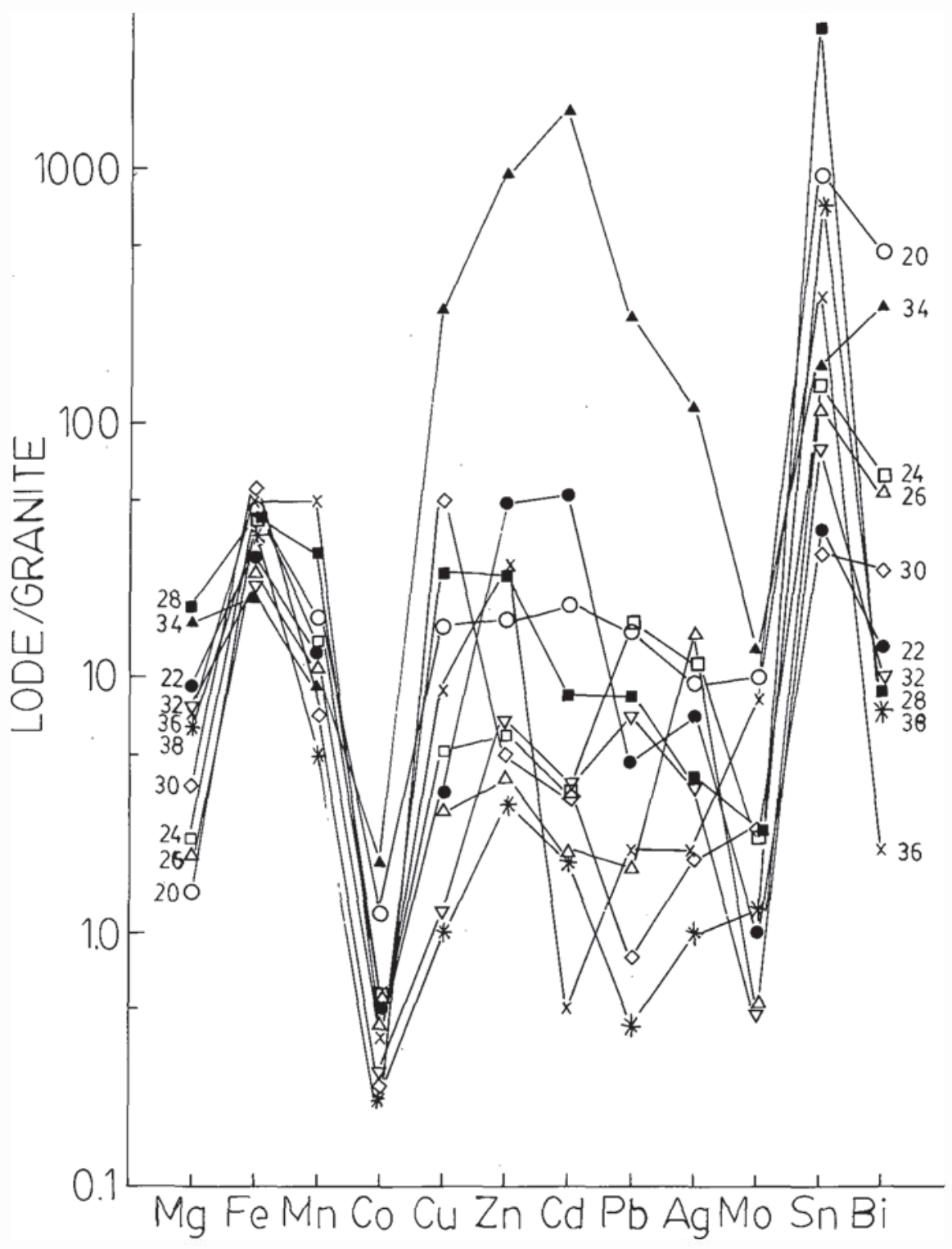

Fig. 9. Ore-element compositions of the lode relative to the "average" True Hill granite. Elements are in no particular order.

The coexistence of low-Fe sphalerite, pyrite and native silver in a Stage 1 assemblage indicates low temperatures (< $200^{\circ} \mathrm{C}$; Lentz, 1986). The coexistence of low-Fe sphalerite (1 wt. $\% \mathrm{FeS}$ ) with pyrite indicates a low sulfur fugacity near the pyritepyrrhotite buffer under reducing conditions $\left(\mathrm{H}_{2} \mathrm{~S} ; \log \left(\mathrm{S}_{2}\right)=-16\right.$ to $-25 @ 100^{\circ}$ to $200^{\circ} \mathrm{C}$; Barton and Skinner, 1979). This coincides with the low temperature stability of septechlorite $\left(<200^{\circ} \mathrm{C}\right)$ and their high ferrous iron content (XRD and Petruk, 1964). Stage 2 fluids were oxidizing, above the hematitemagnetite buffer (hm-mt $\log f\left(\mathrm{O}_{2}\right)=-39$ to $-31 @ 200^{\circ}$ to $300^{\circ} \mathrm{C}$ ). Septechlorite recrystallizes to chlorite during Stage 2 alteration. Phengite is transitional between the characteristics of $1 \mathrm{M}$ and $2 \mathrm{M}$ structures which indicates a depositional temperature between $200^{\circ}$ and $300^{\circ} \mathrm{C}$.

The deposition of fluorite and quartz during Stage 2 occurred either in response to a decrease in fluid temperature or a decrease in geostatic pressure during fluid ascent in the lode which is compatible solubility studies (Holland and Malinin, 1979) and disposition of Stage 2 mineralization in fractures.

\section{Sulfur Isotopes}

Seven sulfur isotope analyses of pyrite (Stage 1) from various portions of the True Hill lodes have an average $\delta^{34} \mathrm{~S}=$ 0.54 per mil with a range of -2.8 to 3.6 per mil (CDT; Table 5). Sulfides in the chlorite-sulfide lode were deposited under reducing conditions from an $\mathrm{H}_{2} \mathrm{~S}$ dominated fluid. At temperatures of approximately $200^{\circ} \mathrm{C}$ the $\delta^{34} \mathrm{~S}$ of $\mathrm{H}_{2} \mathrm{~S}$ would be 2 to 3 per mil lighter than the pyrite (Ohmoto and Rye, 1979). The isotopic compositions and their narrow distribution between -3 and 0 per mil $\delta^{34} S$ favour chemically uniform conditions with a uniform ${ }^{34} S$ fluid composition. The deposition of sulfides (mainly pyrite) from a reduced $\mathrm{H}_{2} \mathrm{~S}$-bearing Stage 1 fluid would decrease the sulfur content and the $\delta{ }^{34} S$ of the fluid. 


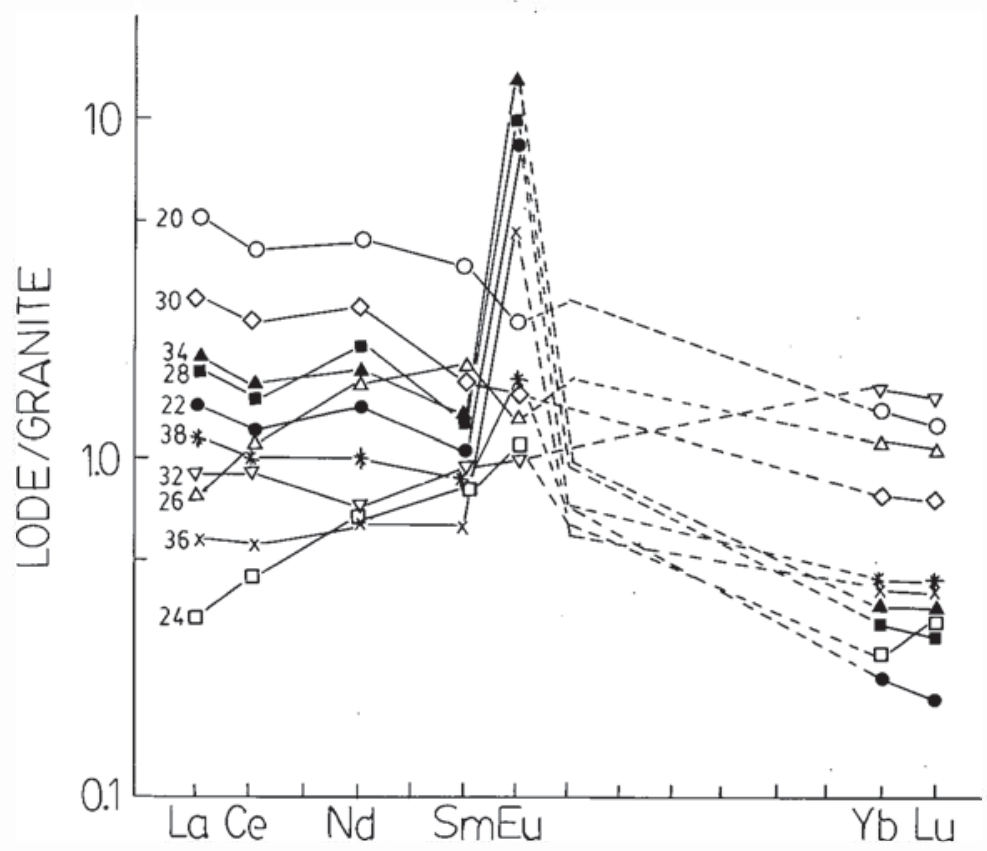

Fig. 10. True Hill granite-normalized REE distribution for lode samples (Table 1) (Gd values are extrapolated from a straight line between Sm and Yb). Solid symbols are metasediment-hosted lode $(22,28,34)$ and the remainder are granite-hosted lodes.

\section{Deposition of Cassiterite}

The deposition of LREE-bearing minerals with $\mathrm{Sn}$ under moderately acid $\mathrm{pH}$ 's suggests similar mechanisms responsible for their deposition. The mobilization of LREE as chloride complexes (Flynn and Burnham, 1978; Alderton et al., 1980; Taylor and Fryer, 1982; Humphris, 1984) indicates Sn-chloride rather than Sn-fluoride complexes are responsible. In order of relative importance based on petrographic observations, the deposition of $\mathrm{Sn}$ resulted from several processes; (1) decrease in effective chlorinity, (2) increase in $\mathrm{pH}$ due to feldspar alteration to K-mica and (3) decrease in temperature resulting from interaction with cool wall rocks. Merits will be discussed in turn.

(1) The most important reaction boundary in the lode is that of chlorite to phengite (equation 1) which involves removal of some $\mathrm{Fe}$ in solution as chloride complexes, with exchange, dehydration, and oxidation reactions. High concentrations of aqueous $\mathrm{KCl}$ and $\mathrm{H}_{4} \mathrm{SiO}_{4}\left(\mathrm{SiF}_{4}\right)$ in the second hydrothermal fluid drives reaction 1 to the right.

$2 \mathrm{Fe}_{5} \mathrm{AlSi}_{3} \mathrm{AlO}_{10}(\mathrm{OH})_{8}+\mathrm{H}_{4} \mathrm{SiO}_{4}+2 \mathrm{KCl}+16 \mathrm{HCl} \rightarrow$ chlorite

$$
\underset{\text { phengite }}{\mathrm{K}_{2} \mathrm{FeAl}_{3} \mathrm{Si}_{1} \mathrm{AlO}_{20}(\mathrm{OH})_{4}}+9 \mathrm{FeCl}_{2}+16 \mathrm{H}_{2} \mathrm{O}
$$

The interaction of $\mathrm{SnCl}_{3}^{-}\left(\mathrm{SnCl}_{2}, \mathrm{SnCl}^{+}\right)$with $\mathrm{Fe}^{2+}$ released during phengitization of chlorite may reduce the effective chlorinity of the hydrothermal fluid (equation 2). The shift in equilibrium of reaction 2, caused by $\mathrm{Fe}$-chloride complexing, will decrease the solubility of $\mathrm{Sn}$ due to a decrease in Sn-chloride complexing. Oxygen balance considerations can be accommodated by the reduction of $\mathrm{Fe}$.
Table 5. Sulfur isotopes.

\begin{tabular}{lc} 
(DDH-depth) & $\delta^{34} \mathrm{~S}(\mathrm{CDT})$ \\
\hline $80-03-283 \mathrm{ft}$ & -1.6 \\
$80-03-314 \mathrm{ft}$ & 2.5 \\
$80-03-386 \mathrm{ft}$ & 0.3 \\
$82-5-55.3 \mathrm{~m}$ & 0.4 \\
$82-06-293 \mathrm{~m}$ & 0.4 \\
$82-13-238 \mathrm{~m}$ & -2.8 \\
Trench 7b & 3.6 \\
\hline
\end{tabular}

$\mathrm{SnCl}_{3 \mathrm{aq}}+\mathrm{Fe}^{2+}{ }_{\mathrm{chl}} \longrightarrow \mathrm{Sn}^{2+}+\mathrm{FeCl}_{2 \mathrm{aq}}+\mathrm{Cl}_{2 \mathrm{q}}^{-}$

$\log \mathrm{K}_{\mathrm{t}}=-3.69=\log \mathrm{K}_{1}-\log \mathrm{K}_{2}$

$\mathrm{SnCl}_{3 \text { mq }} \rightarrow \mathrm{Sn}^{2+}+3 \mathrm{Cl}^{-}$

$\log \mathrm{K}_{1}=-8.2$ Patterson et al. (1981)

$\mathrm{FeCl}_{2 \mathrm{eq}} \rightarrow \mathrm{Fe}^{2+}+2 \mathrm{Cl}_{\text {«q }}^{-}$

$\log \mathrm{K}_{2}=-4.53$ Crerar and Barnes (1976)

The exact $\mathrm{Sn}-\mathrm{Cl}$ ligation number is not known, but calculations by Patterson et al. (1981) indicate that $\mathrm{SnCl}^{+}, \mathrm{SnCl}_{2}$ and $\mathrm{SnCl}_{3}$ are the dominant chloride species in acidic chloride solutions acidic pH's (Jackson and Helgeson, 1985a; Eugster, 1985; Eadington, 1988), but neutral species are probably most stable at higher temperatures because of the decreasing dielectric constant 
of water with higher temperatures. The deposition of LREE along the chlorite-sulfide/hematite-phengite reaction front resulted from, in part, a decrease in the chloride ligands available for complexing with LREE due to an increase in Fe-chloride complexing upon interaction with the chlorite-sulfide assemblage.

(2) Hydrolysis reactions may be responsible for the deposition of cassiterite along the granite-lode margin during the second mineralizing event. The increase in $\mathrm{pH}$ caused by hydrolysis results in the decreased solubility of Sn-chloride complexes in the fluid (Alderton et al., 1980; Patterson et al., 1981; Eugster, 1985; Jackson and Helgeson, 1985a, b; Eadington, 1988). Alderton et al. (1980) proposed a pH mechanism for the deposition of REE which may be applicable to this study (equation 5).

$$
\begin{aligned}
& \mathrm{MA}^{3-\mathrm{n}}+3 / 2 \mathrm{H}_{2} \mathrm{O} \rightarrow 1 / 2 \mathrm{M}_{2} \mathrm{O}_{3}+3 \mathrm{H}^{+}+\mathrm{nA}^{-} \\
& \mathrm{M}=\mathrm{REE}\left(\text { or } \mathrm{Sn}^{2+}\right), \mathrm{A}=\mathrm{F}, \mathrm{Cl}, \mathrm{n}=0,1,2,3
\end{aligned}
$$

The deposition of REE along the boundary between the hematitephengite assemblage and the granite may be in response to an increase in $\mathrm{pH}$ during feldspar hydrolysis.

(3) A decrease in temperature of Stage 2 fluids while interacting with (cooler) granite porphyry could be responsible for the deposition of the Sn with LREE and, to a lesser extent, with HREE. The $\mathrm{Sn}^{2+} / \mathrm{Sn}^{4+}$ boundary is postulated to be 10 to 40 $\log \mathrm{f}\left(\mathrm{O}_{2}\right)$ units above the $\mathrm{SO}_{4}{ }^{2} / \mathrm{H}_{2} \mathrm{~S}$ boundary at $350^{\circ} \mathrm{C}$ (Patterson et al., 1981) but moves to lower oxygen fugacities at lower temperatures resulting in the very low solubility of tin below $250^{\circ} \mathrm{C}$ (Jackson and Helgeson, 1985a).

\section{DISCUSSION}

The Stage 1 chlorite-sulfide and Stage 2 hematite-phengitefluorite-cassiterite assemblages are also present in Cornish tinlode deposits such as the Wheal Jane (Rayment et al., 1971), Mount Wellington tin deposit (Kettaneh and Badham, 1978), and the Levant tin-sulfide deposit (Jackson et al., 1982). The mineral paragenesis and inferred zonation found at True Hill is similar but less complex than the tin lode deposits in Cornwall, England (Rayment et al., 1971; Kettaneh and Badham, 1978; Hosking, 1979; Taylor, 1979; Jackson et al., 1982; Strong, 1988) and in Nova Scotia (Pitre and Richardson, 1989).

Fluid inclusion and isotope studies from other tin deposits indicate moderate temperatures $\left(250^{\circ}\right.$ to $\left.350^{\circ} \mathrm{C}\right)$ and moderate salinities (10 wt. \% salts) (Kelly and Turneaure, 1970; Kelly and Rye, 1979; Patterson et al., 1981; Jackson et al., 1982; Norman and Transcotchasan, 1982; Jackson and Helgeson, 1985b; Davis and Williams-Jones, 1985; Samson, 1990). Fluid inclusions in tin-sulfide lodes at Mount Pleasant are dominated by liquidvapour inclusions with temperatures ranging from $100^{\circ} \mathrm{C}$ to $350^{\circ} \mathrm{C}$ and 0 to 10 wt. \% eq. $\mathrm{NaCl}$ (Samson, 1990 ). This may be compatible with either a supercritical magmatic fluid (low salt) or a condensed fluid interacting with cooling meteoric water. Commonly, magmatic fluids have moderate salinities (15-17 wt. $\%$ eq. $\mathrm{NaCl}$ ) upon fluid-phase separation (Burnham and Ohmoto,
1980). The development of Stage 1 and Stage 2 assemblages are postulated to be derived from a crystallizing magma at depth which intruded the True Hill granite porphyry. The lack of hydrothermal alteration at depth in the True Hill granite would obstruct meteoric fluid influx from the margins of the lode; however, this does not preclude meteoric or formation waters derived at a considerable depth below True Hill.

The enrichment of $\mathrm{Fe}, \mathrm{Mg}, \mathrm{Mn}$, and other chalcophile elements and sulfur in the fluid responsible for stage 1 (chloritesulfide) may represent early magmatic degassing at depth. Strong partitioning of chalcophile elements into a supercritical fluid from a granite (Holland, 1972; Candela and Holland, 1984; Whitney et al., 1985), as well as $\mathrm{H}_{2} \mathrm{~S}$ and $\mathrm{H}_{2}$ with $\mathrm{H}_{2} \mathrm{O}$, could be responsible for the chlorite-sulfide assemblage. Alternatively, alteration of ferromagnesium phases in the True Hill granite at considerable depth could enrich the Stage 1 fluid in $\mathrm{Fe}, \mathrm{Mg}$ and Mn. The Stage 1 fluids have characteristic moderately acidic pH's and low $f\left(\mathrm{O}_{2}\right)$ and $f\left(\mathrm{~S}_{2}\right)$ similar to other tin-sulfide lodes. Stage 2 mineralization is characterized by alkali and hydrogen metasomatism which produced enrichment of trace elements (Sn, Th, U, Ta, Nb, and Y). These siliceous, fluorine and alkali fluids are characteristics of magmatic-hydrothermal fluids and may have been derived from a volatile-saturated magma. Reaction between the Stage 2, Sn- and REE-bearing fluid and the preexisting chlorite-sulfide assemblage and granite are responsible deposition of cassiterite and monazite. The Stage 2 fluid is estimated to have been oxidized ( $>\mathrm{hm}$-mt buffer) not far from the $\mathrm{Sn}^{2+} / \mathrm{Sn}^{4+}$ boundary. The low solubility of $\mathrm{Sn}$ in high $\mathrm{f}\left(\mathrm{O}_{2}\right)$ fluids may account for the subeconomic nature of this deposit.

The Stage 1 fluid apparently leached the REE-bearing phases from the granite, hence the overprinting by the Stage 2 fluid has introduced almost all of the REE except possibly some of the HREE tied up in trace zircon and rutile. The REE enrichment (Stage 2) may be due to partitioning into a hydrothermal fluid during second boiling of a granitic magma at depth (Flynn and Burnham, 1978) or leaching the granites at depth. The alteration of plagioclase (Fowler and Doig, 1983) may be responsible for the enrichment Eu in the hydrothermal fluid although the high Eu in metasediment-hosted lodes seems to be inherited. Incongruent alteration of LREE-bearing phases and plagioclase by weakly acidic, high-Cl fluids may be responsible for their enrichment in the Stage 2 fluids. Tin may be partitioned into a volatile phase during magmatic degassing similar to $\mathrm{Zn}, \mathrm{Mn}, \mathrm{Fe}$ and $\mathrm{Cu}$ (Holland, 1972) or $\mathrm{Eu}^{2+}$ (Flynn and Burnham, 1978). However, leaching of Sn during alteration of biotite at considerable depth may not be precluded.

Although there are many similarities between True Hill lodes and lodes at Mount Pleasant, their are a few differences: (i) there is no documentation of two stages of mineralization within the Mount Pleasant lodes, (ii) the MP lodes host a single stage of cassiterite, stannite, pyrite, pyrrhotite, sphalerite and $\mathrm{Cu}$ sulfide mineralization similar to those in Cornwall contrast to that of True Hill and (iii) the oxidation state of the lodes in the North Zone (MP) is very low compared to the Stage 2 assemblages at True Hill. The cassiterite-bearing hematite-phengite assemblage is unique with respect to $S n$ lode mineralization world wide.

The change in $\mathrm{f}\left(\mathrm{O}_{2}\right)$ from Stage 1 to Stage 2 may be due to 
either magmatic-oxidation resulting from degassing of $\mathrm{H}_{2}$ and $\mathrm{H}_{2} \mathrm{~S}$ fluids (Stage 1) from a granite emplaced at depth below True Hill or two unrelated fluids sources (different $\mathrm{T}, \mathrm{pH}, \mathrm{f}\left(\mathrm{O}_{2}\right)$, etc.).

\section{CONCLUSIONS}

(1) Field observations indicate that lode mineralization at True Hill occurred along structures (fractures and faults) transecting the granite and metasedimentary rocks.

(2) Two distinct mineralizing episodes occurred within the lodes, represented by an early chlorite-sulfide assemblage (Stage 1) and a later hematite-phengite-cassiterite assemblage (Stage 2).

(3) The Stage 1 assemblage contains $\mathrm{Mn}$ - and $\mathrm{Fe}^{2+}$-rich septechlorite (XRD), pyrite, sphalerite, galena, chalocopyrite, $\mathrm{Pb}$ - $\mathrm{Bi}$ sulfides, and native $\mathrm{Ag}$ which formed at low temperatures $\left(<200^{\circ} \mathrm{C}\right)$. Intense $\mathrm{Fe}, \mathrm{Mg}, \mathrm{Mn}$ and $\mathrm{H}_{2} \mathrm{~S}$ metasomatism, as well as the enrichment of chalcophile elements, implies high chloride concentrations. Chloritization (weakly acidic) within the faultcontrolled lode was intense and leached alkali and alkali-earth elements from the host granite and metasedimentary rock. The coexistence of low-Fe sphalerite indicates low $\mathrm{f}\left(\mathrm{O}_{2}\right)$ and low $\mathrm{f}\left(\mathrm{S}_{2}\right)$ conditions for the Stage 1 fluid. The narrow variation of $\delta$ ${ }^{34} \mathrm{~S}$ near 0 per mil for pyrite indicates uniform conditions during deposition from a fluid phase with $\mathrm{a} \delta 34 \mathrm{~S}$ of between -3 and 0 per mil.

(4) Stage 2 (hematite-phengite-cassiterite) mineralization overprints the Stage 1 chlorite-sulfide assemblage. Interaction of weakly acidic, alkali-rich fluids with Stage 1 assemblages produced complex alteration. These fluids caused feldspar hydrolysis in the selvages adjacent to granite. Late quartz and fluorite veins and alteration are present, albeit uncommon. The high $\mathrm{f}\left(\mathrm{O}_{2}\right)$ of the fluid led to oxidation and desulfidation of the preexisting chlorite-sulfide (Stage 1) assemblage, as well as oxidation of biotite and ilmenite to produce rutile in the metasedimenthosted portions of the lodes. The association of LREE minerals with cassiterite in the vicinity of the reaction front of Stage 1 and Stage 2 assemblages and the granite lode contact indicates chloride complexing under weakly acidic conditions.

(5) In order of relative importance, deposition of cassiterite along a reaction front between Stage 2 assemblage and the chlorite-sulfide assemblage and the granite is probably related to (i) a decrease in effective chlorinity of the fluid, (ii) an increase in $\mathrm{pH}$ due to feldspar hydrolysis at the granite/lode contact and (iii) a decrease in temperature which may have been caused by interaction with the cooler granite porphyry.

(6) Interpretation of geologic observations, whole rock and mineral composition and sulfur isotopes supports magmatichydrothermal origin for the two stages of mineralization. The evidence favours partitioning of tin into a fluid phase during second boiling of a crystallizing granitic magma, as a stannous species, but the higher $\mathrm{f}\left(\mathrm{O}_{2}\right)$ of the fluid inhibited more significant enrichment due to the lower solubility of Sn under these conditions. The spatial relationship and origin of the chloritesulfide and hematite-phengite assemblages is much more problematical, but a two-stage or progressive devolatilization of the underlying magma may explain both the change in redox conditions and chemical compositions of the fluids which formed the lode. Alternately, the two assemblages may reflect different fluid sources.

\section{ACKNOWLEDGEMENTS}

D.L. is indebted to Billiton Canada Limited for their generous financial support and access to company information. J. Atkinson and G. Lutes recommended this project. We are also grateful to M. McLeod(D.N.R.N.B) and Dr. G. Kooiman (Mount Pleasant Mines Limited) for many helpful discussions. I (D.L.) would also like to thank S. Townsend, J. Vahtra and Dr. H. DeSouza for technical assistance and support. Lastly, I would like to thank L. Fyffe, D. Kontak, C.E. Seedorff, D. Sinclair, P. Smith, D. Watanabe for their helpful suggestions.

ALDERTON, D.H.M., PEARCE, J.A., and POTTS, P.J. 1980. Rareearth element mobility during granite alteration: evidence from southwest England. Earth and Planetary Science Letters, 49, pp. 149-165.

BARTON, P.B. and SKINNER, B.J. 1979. Sulfide Mineral Stabilities. In Geochemistry of Hydrothermal Ore Deposits. Second edition. Edited by H.L. Bames. John Wiley and Sons Limited, New York, New York, pp. 71-136.

BURNHAM, C.W. and OHMOTO, H. 1980. Late stage processes in felsic magmatism. In Granitic magmatism and related mineralization. Edited by S. Ishihara and S. Takenouchi. Mining Geology, Special Issue No. 8, Society of Mining Geologists, Japan, pp. 1-11.

CANDELA, P. and HOLLAND, H.D. 1984. The partitioning of copper and molybdenum between silicate melts and aqueous fluids. Geochimica et Cosmochimica Acta, 48, pp. 373-380.

CARROLL, D. 1970. Clay Minerals: A Guide to their X-Ray Identification. Geological Society of America, Special Paper 126, 80 p.

CRERAR, D.A. and BARNES, H.L. 1976. Ore solution chemistry v. solubilities of chalcopyrite and chalcocite assemblages in hydrothermal solution at $200^{\circ}$ to $350^{\circ} \mathrm{C}$. Economic Geology, 71, pp. 772 794.

DAGGER, G.W. 1972. Genesis of the Mount Pleasant tungstenmolybdenum deposit, New Brunswick. Institute of Mining and Metallurgy, Transactions Section B, 81, pp. 73-102.

DAVIS, W.J. and WILLIAMS-JONES, A.E. 1985. A fluid inclusion study of porphyry-greisen, tungsten-molybdenum deposit at Mount Pleasant, New Brunswick, Canada. Mineralium Deposita, 49, pp. 7-23.

EADINGTON, P.J. 1988. The solubility of cassiterite in hydrothermal solutions in relation to some lithological and mineral associations in tin ores. In Recent Advances in the Geology of Granite-Related Mineral Deposits. Edited by R.P. Taylor and D.F. Strong. CIM Special Volume 39, pp. 25-32.

EUGSTER, H.P. 1985. Granites and hydrothermal ore deposits: A geochemical framework. Mineralogical Magazine, 49, pp. 7-23.

FLYNN, R.T. and BURNHAM, C.W. 1978. An experimental determination of Rare Earth Partition Coefficients between a chloride containing Vapour Phase and Silicate Melts. Geochimica et Cosmochimica Acta, 42, pp. 685-701.

FOWLER, A.D. and DOIG, R. 1983. The significance of europium anomalies in the REE spectra of granites and pegmatites, Mont Laurier, Quebec. Geochimica et Cosmochimica Acta, 47, pp. 1131-1137.

HEY, M.H. 1954. A new review of the chlorites. Mineralogical Magazine, 30, pp. 277-292.

HOLLAND, H.D. 1972. Granites, Solutions, and Base Metal Deposits. Economic Geology, 67, pp. 281-301.

HOLLAND, H.D. and MALININ, S.D. 1979. The Solubility and Occurrence of Non-Ore Minerals. In Geochemistry of Hydrothermal Ore Deposits. Edited by H.L. Bames. John Wiley and Sons 
Limited, New York, New York, pp. 461-508.

HOSKING, K.F.G. 1979. Tin Distribution Pattems. Geological Society of Malaysia Bulletin, 11, pp. 1-70.

HUMPHRIS, S.E. 1984. The Mobility of the Rare Earth Elements in the Crust. In Rare Earth Element Geochemistry. Edited by P. Henderson. Elsevier, New York, New York, pp. 317-342.

JACKSON, K.J. and HELGESON, H.C. 1985a. Chemical and thermodynamic constraints on the hydrothermal transport and deposition of tin: I. Calculation of the solubility of cassiterite at high pressures and temperatures. Geochimica et Cosmochimica Acta, 49, pp. 1-22.

1985b. Chemical and thermodynamic constraints on the hydrothermal transport and deposition of tin: II. Interpretation of phase relations in the Southeast Asian Tin Belt. Economic Geology, 80, pp. 1365-1378.

JACKSON, N.J., HALLIDAY, A.N.,SHEPPARD, S.M.F., and MTTCHELL, J.G. 1982. Hydrothermal activity in the St. Just Mining District, Comwall, Endland.In Metallization Associated with Acid Magmatism. Edited by A.M. Evans. John Wiley and Sons Limited, pp. 137-179.

KELLY, W.C. and RYE, R.O. 1979. Geologic, Fluid Inclusion, and Stable Isotope Studies of the Tin-Tungsten Deposits of Panasqueria, Portugal. Economic Geology, 74, pp. 1721-1822.

KELLY, W.C. and TURNEAURE, F.S. 1970. Mineralogy, paragenesis and geothermometry of the tin and tungsten deposits of the Eastern Andes, Bolivia. Economic Geology, 65, pp. 609-680.

KETTANEH, Y.T. and BADHAM, J.P.N. 1978. Mineralization and Paragenesis at the Mount Wellington Mine, Cornwall. Economic Geology, 73, pp. 486-495.

KOOIMAN, G.J., McLEOD, M.J., and SINCLAIR, W.D. 1986. Porpyry Tungsten-Molybdenum Orebodies, Polymetallic Veins and Replacement Bodies, and Tin-bearing Greisen Zones in the Fire Tower Zone, Mount Pleasant, New Brunswick. Economic Geology, 81, pp. 1356-1373.

LENTZ, D.R. 1986. Geology and Depositional Conditions of Tin lodes at True Hill, New Brunswick. Unpublished M.Sc. thesis, University of New Brunswick, 280 p.

LENTZ, D.R., LUTES, G.G., and HARTREE, R. 1988. Bi-Sn-W-Mo greisen mineralization associated with the True Hill granite, southwestern N.B. Maritime Sediments and Atlantic Geology, 24, pp. 321-338.

MONTOYA, J.W. and HEMLEY, J.J. 1975. Activity relations and stabilities in alkali feldspars and mica alteration reactions. Economic Geology, 70, pp. 577-583.

MULLIGAN, R. 1975. Geology of Canadian tin occurrences. Geological Survey of Canada, Economic Geology Report No. 28, 155 p.

NORMAN, D.I. and TRANSCOTCHASAN, Y. 1982. Mineralization and Fluid Inclusion Study of the Yod Nam Tin Mine, Southem Thialand. In Mineralization Associated with Acid Magmatism. Edited by A.M. Evans. John Wiley and Sons Limited, New York, New York, pp. 261-272.

OHMOTO, H. and RYE, R.O. 1979. Isotopes of Sulfur and Carbon. In Geochemistry of Hydrothermal Ore Deposits. Edited by H.L. Barnes. John Wiley and Sons Limited, New York, New York, pp. 509-567.

PARRISH, I.S. 1977. Mineral catalog for the Mount Pleasant Deposit of New Brunswick Tin Mines. Canadian Mineralogist, 15, pp. 121126.

PARRISH, I.S. and TULLY, J.V. 1978. Porphyry tungsten zones at Mt. Pleasant, N.B. Canadian Institute of Mining and Metallurgy Bulletin, 71, pp. 93-100.

PATTERSON, D.J., OHMOTO, H., and SOLOMON, M. 1981. Geologic setting and genesis of cassiterite-sulfide mineralization at Renison Bell, westem Tasmania. Economic Geology, 76, pp. 393.
438.

PETRUK, W. 1964. Mineralogy of the Mount Pleasant Tin Deposit in New Brunswick. Canada Mines Branch Technical Bulletin, 56, 37 p.

PETRUK, W. 1973. The tungsten-molybdenum-bismuth deposit of Brunswick Tin Mines Limited: It's mode of occurrence, mineralogy, and amenability to mineral benifaction. Canadian Institute of Mining and Metallurgy Bulletin, 66, pp. 113-130.

PITRE, C.V. and RICHARDSON, J.M. 1989. Paragenesis of veins of the Duck Pond tin prospect, Meguma Group, East Kempville, Nova Scotia. Canadian Joumal of Earth Sciences, 26, pp. 2032-2043.

POULIOT, G., BARONDEAU, B., SAUVE, P., and DAVIS, M. 1978. Distribution of alteration minerals and metals in the Fire Tower zone at Brunswick Tin Mines Limited, Mount Pleasant area, New Brunswick. Canadian Mineralogist, 16, pp. 223-237.

RAYMENT, B.D., DAVIS, G.R., and WILSON, J.D. 1971. Controls to mineralization at Wheal Jane, Comwall. Transactions of the Institute of Mining and Metallurgy, Section B, 80, pp. B224-B237.

RUTTENBERG, A.A. 1963. Tin Mineralization and Associated Rock Alterations at Mount Pleasant, Charlotte County, New Brunswick. Unpublished M.Sc. thesis, University of New Brunswick, 172 p.

RUITENBERG, A.A. and FYFFE, L.R. 1982. Mineral Deposits associated with granitoid intrusions and related subvolcanic stocks in New Brunswick and their relationship to Appalachian tectonic evolution. Canadian Institute of Mining and Metallurgy Bulletin, 75, pp. 83-97.

RUITENBERG, A.A. and McCUTCHEON, S.R. 1985. Tungsten, Molybdenum, and Tin Deposits in New Brunswick. Geological Association of Canada/Mineralogical Association of Canada, Field Trip Guidebook, Excursion 13, 33 p.

SAMSON, I.M. 1990. Fluid evolution and mineralization in a subvolcanic granite stock: The Mount Pleasant W-Mo-Sn deposits, New Brunswick. Geological Association of Canada/Mineralogical Association of Canada, Program with Abstracts, 15.

SINCLAIR, W.D., KOOIMAN, G.J.A., and MARTIN, D.A. 1988. Geological setting of granites and related tin deposits in the North Zone, Mount Pleasant, New Brunswick. In Current Research, Part B, Geological Survey of Canada, Paper 88-1B, pp. 201-208.

STRONG, D.F. 1988. A review and model for granite-related mineral deposits. In Recent Advance in the Geology of Granite-Related Mineral Deposits. Edited by R.P. Taylor and D.F. Strong. CIM Special Volume 39, pp. 424-445.

TAYLOR, R.G. 1979. Geology of Tin Deposits. Elsevier, New York, New York, 217 p.

TAYLOR, R.P. and FRYER, B.J. 1982. Rare-earth Element Geochemistry as an Aid to Interpreting Hydrothermal Ore Deposits. In Metallization Associated with Acid Magmatism. Edited by A.M. Evans. John Wiley and Sons Limited, New York, New York, pp. 357-365.

TAYLOR, R.P., SINCLAIR, W.D., and LUTES, G.G. 1985. Geochemical and Isotopic Characterization of Granites Related to WSn-MoMineralization in the Mount Pleasant Area, New Brunswick. In Granite Related Mineral Deposits. Edited by R.P. Taylor and D.F.Strong. Canadian Institute of Mining and Metallurgy, pp. 265 273.

WAKITA, H., REY, P., and SCHMITT, R.A. 1971. Abundances of the 14 rare-earth elements and 12 other trace elements in Apollo 12 samples: five igneous and one breccia rocks and four soils. Proceedings of the second Lunar Science Conference, pp. 1319-1329.

WHITNEY, J.H., HEMLEY, J.J., and SIMON, F.O. 1985. The Concentration of Iron in Chloride Solutions Equilibrated with Synthetic Granite Compositions: The Sulfur-Free System. Economic Geology, 80, pp. 444-460. 
APPENDIX : Sample locations

1a. Chemical Analyses

$\begin{array}{cll}\text { SAMPLE \# } & & \text { DDH\#-DEPTH } \\ & \\ 20 & & 82-06-285.6 \mathrm{~m} \\ 22 & 82-13-050.1 \mathrm{~m} \\ 24 & 82-06-288.5 \mathrm{~m} \\ 26 & 82-06-317.4 \mathrm{~m} \\ 28 & 82-15-062.3 \mathrm{~m} \\ 30 & 82-24-165.9 \mathrm{~m} \\ 32 & 83-01-284.9 \mathrm{~m} \\ 34 & 82-15-038.1 \mathrm{~m} \\ 36 & \text { Trench 7b } \\ 38 & 82-27-214.6 \mathrm{~m}\end{array}$

STAGE HOST ROCK

$\begin{array}{ll}\text { Stage 1 and 2 } & \begin{array}{l}\text { (granite-hosted) } \\ \text { (metasediment-hosted) } \\ \text { Stage 1 and 2 }\end{array} \\ \text { Stage 2 } & \text { (granite-hosted) } \\ \text { Stage 1 and 2 } & \text { (granite-hosted) } \\ \text { Stage 1 and 2 } & \text { (metasediment-hosted) } \\ \text { Stage 1 and 2 } & \text { (granite-hosted) } \\ \text { Stage 1 and 2 } & \text { (granite-hosted) } \\ \text { Stage 1 } & \text { (metasediment-hosted) } \\ \text { Stage 1 and 2 } & \text { (granite-hosted) } \\ \text { Stage 1 and 2 } & \text { (granite-hosted) }\end{array}$

